*aMIS View/Print Document Cover Sheet

This document was retrieved from the Boeing ISEARCH System.

Accession \#: D196054482

Document \#: SD-WM-ER-423

Title/Desc:

TANK 241C108 HEADSPACE GAS \& VAPOR

CHARACTERIZATION RESULTS FOR SAMPLES COLLECTED IN $7 / 1993 \& 8 / 1994$ 


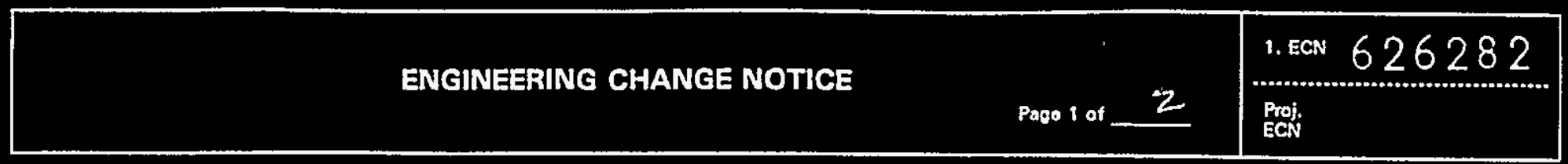

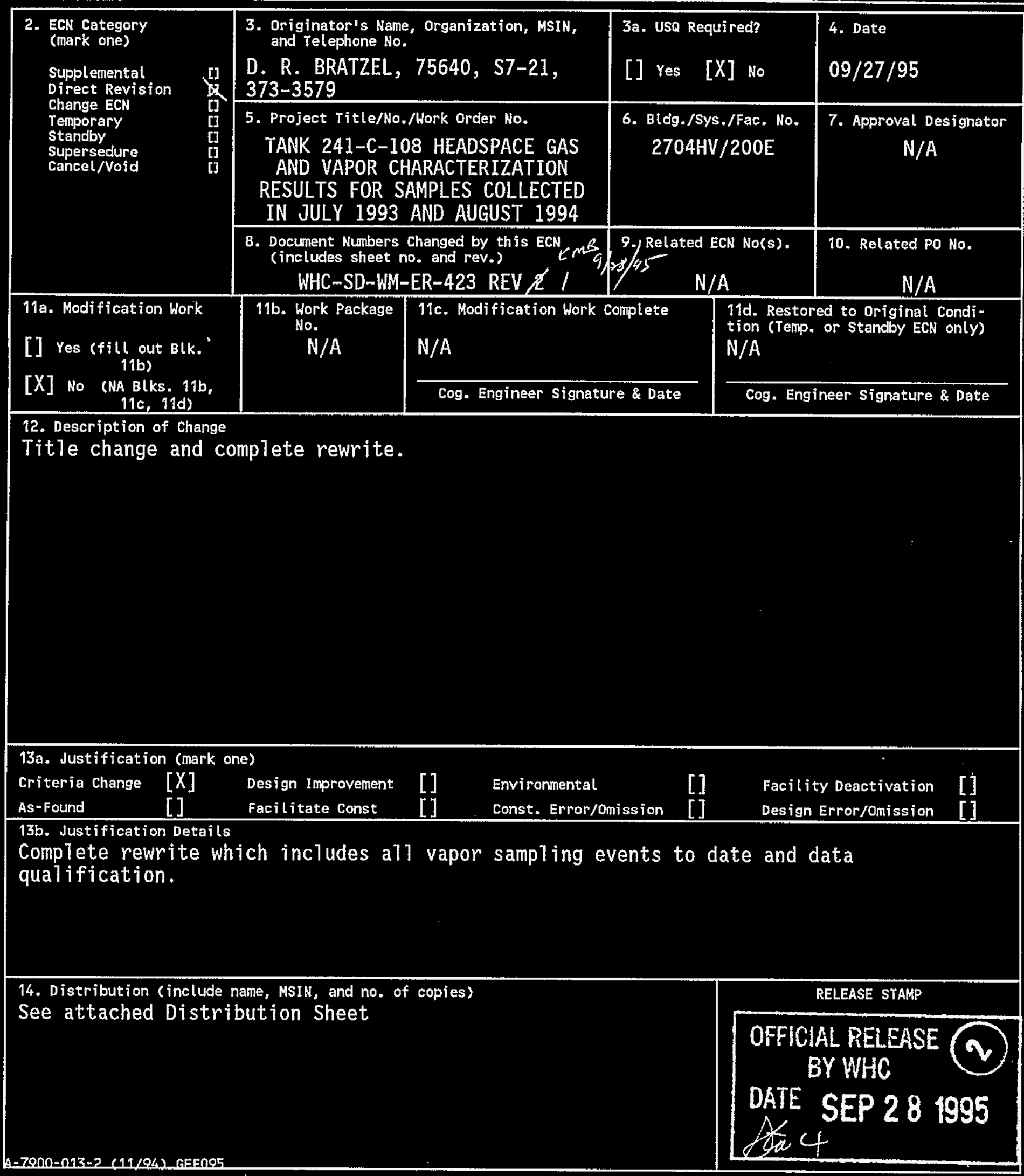




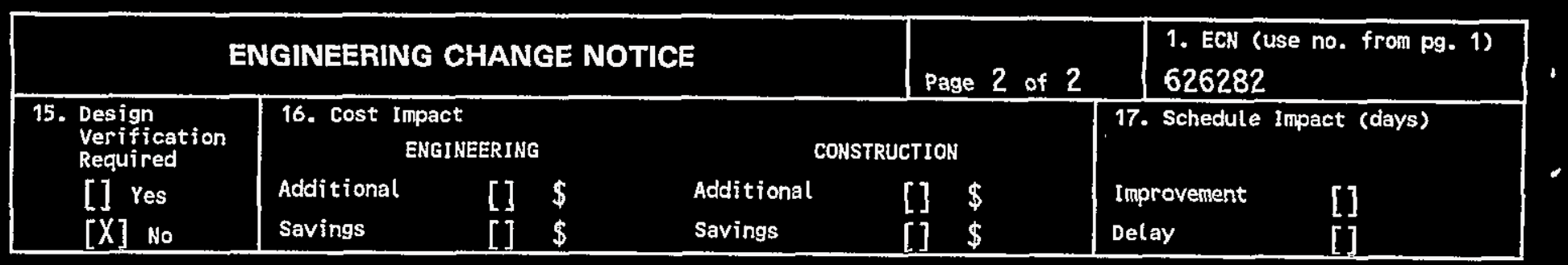

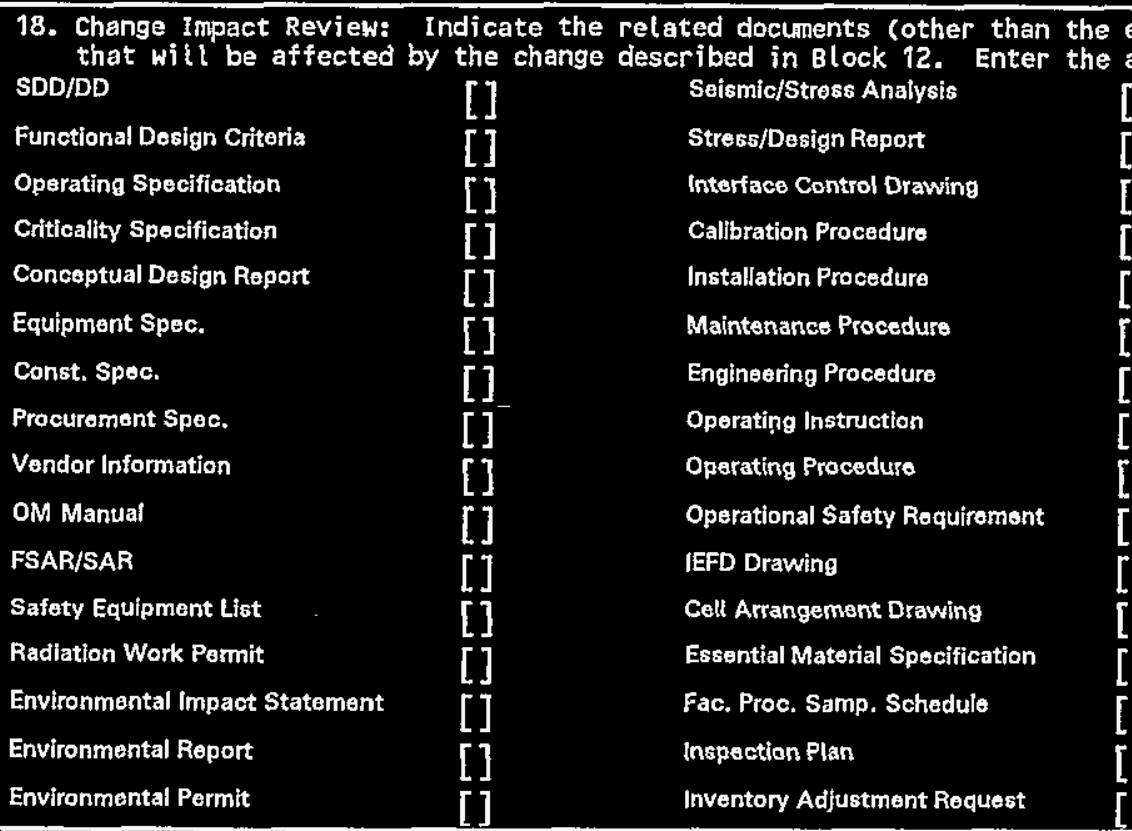

19. Other Affected Documents: (NOTE: Documents listed below will not be revised by this ECW.) Signatures below indicate that the signing organization has been notified of other affected documents tisted below. Document Number/Revision Doctment Number/Revision

$\begin{array}{lll}{[]} & \text { Tank Callbration Manual } & {[]} \\ {[]} & \text { Health Physics Procedure } & {[]} \\ {[]} & \text { Spares Multiple Unit Listing } & {[]} \\ {[]} & \text { Test Procedures/Specification } & {[]} \\ {[]} & \text { Component Index } & {[]} \\ {[]} & \text { ASME Coded Item } & {[]} \\ {[]} & \text { Human Factor Consideration } & {[]} \\ {[]} & \text { Computer Software } & {[]} \\ {[]} & \text { Electric Circuit Scheduie } & {[]} \\ {[]} & \text { ICRS Procedure } & {[]} \\ {[]} & \text { Process Control Manual/Plan } & {[]} \\ {[]} & \text { Process Flow Chart } & {[]} \\ {[]} & \text { Purchase Requisition } & {[]} \\ {[]} & \text { Tickler File } & {[]} \\ {[]} & & {[]} \\ {[]} & & {[]}\end{array}$

1

Document Number Revision

20. Approvals
OPERATIONS AND ENGLWEERING
Cog. Eng. D. R. Bratzel
Cog. Mgr. T. J. Kelley
QA
Safety
Environ.
Other
Proj.
Proj.
Proj.
Proj.




\section{RELEASE AUTHORIZATION}

Document Number: WHC-SD-WM-ER-423, REV 2

Document Title: Tank 241-C-108 Headspace Gas and Vapor

Characterization Results for Samples Collected in July 1993 and August 1994

Release Date: $\quad 9 / 28 / 95$

This document was reviewed following the procedures described in WHC-CM-3-4 and is:

APPROVED FOR PUBLIC RELEASE

WHC Information Release Administration Specialist:
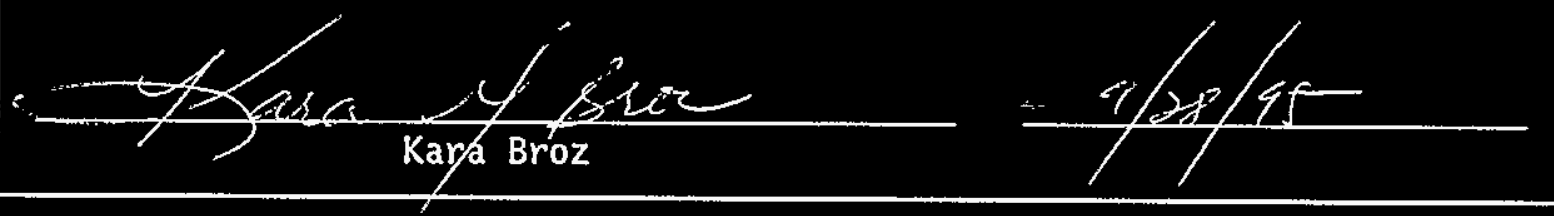

TRADEMARK DISCLAIMER. Reference herein to any specific commercial product, process, or service by trade name, trademark, manufacturer, or otherwise, does not necessarily constitute or imply its endorsement, recommendation, or favoring by the United States Government or any agency thereof or its contractors or subcontractors.

This report has been reproduced from the best available copy. Available in paper copy. Printed in the United States of America. To obtain copies of this report, contact:

Westinghouse Hanford Company - Document Control Services

P.0. Box 1970, Mailstop H6-08, Richland, WA 99352

Telephone: (509) 372-2420; Fax: (509) 376-4989 

2. Title

TANK 241-C-108 HEADSPACE GAS AND VAPOR

CHARACTERIZATION RESULTS FOR SAMPLES COLLECTED IN JULY 1993 AND AUGUST 1994

\section{Key Words}

CHARACTERIZATION OBJECTIVES, TANK HEADSPACE,

SAMPLING EVENT, INORGANIC GASES, ORGANIC VAPORS

3. Number

WHC-SD-WM-ER-423

4. Rev No.

2

6. Author

Nane: D. R. BRATZEL.

signature $P R B$, th $9 / 25 / 95$

Organization/Charge code $75640 / N 4 A B 1$

\section{Abstract}

Significant changes have been made to ali of the original vapor characterization reports. This report documents specific headspace gas and vapor characterization results for a17 vapor sampling events to date. In addition, changes have been made to the original vapor reports to qualify the data based on quality assurance issues associated with the performing laboratories.

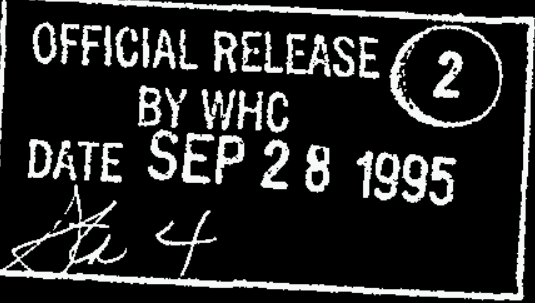




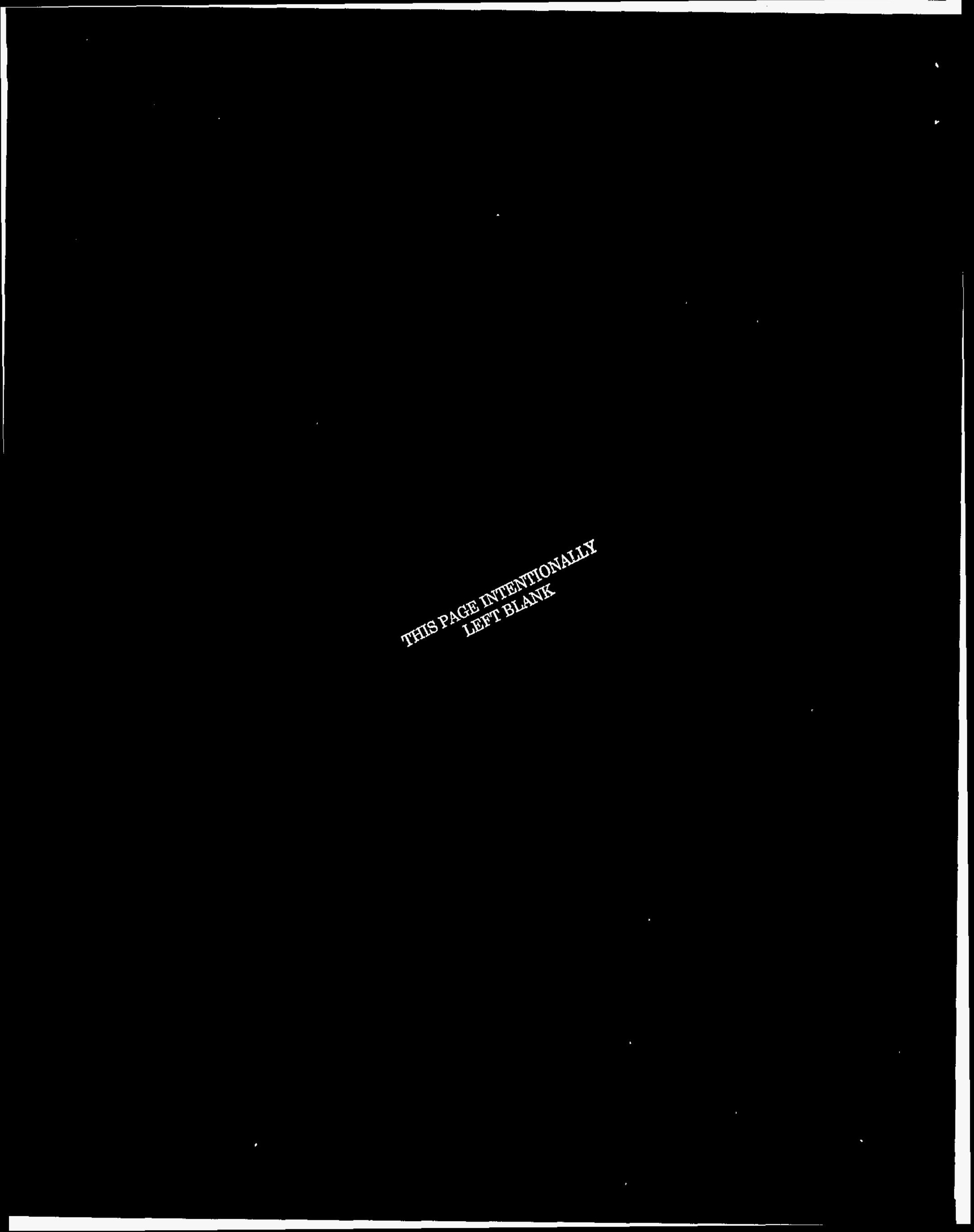




\begin{tabular}{|c|c|c|c|c|}
\hline & RECORD OF REVISION & $\begin{array}{l}\text { (1) Document Nu } \\
W H C-S D-W M-E\end{array}$ & -423 & Page 1 \\
\hline $\begin{array}{l}\text { (2) Title } \\
\text { TANK 241-C- } \\
\text { IN JULY } 19 \text {. }\end{array}$ & $\begin{array}{l}08 \text { HEADSPACE GAS AND VAPOR CHARACTERIZATION } \\
\text { AND AUGUST } 1994\end{array}$ & ULTS FOR & ES & ECTED \\
\hline & CHANGE CONTROL RECORD & & & \\
\hline (3) Revision & (4) Description of change - Replace, Add, and Delete Pages & Authori & ed for & \\
\hline 0 & $\begin{array}{l}\text { (7) WHC-SD-WM-ER-423, REV. 0, EDT } 159095 \\
\text { May 31, } 1995\end{array}$ & (5) Cog. Engr. & (6) $c$ & Mgr. Date \\
\hline 1 & $\begin{array}{l}\text { Made editorial changes and added } \\
\text { information in organice vapor chapter. ECN } \\
623546\end{array}$ & & & \\
\hline RS. 2 & $\begin{array}{l}\text { Complete revision and title change. ECN } \\
626282\end{array}$ & th & & $9 / 200 / 8$ \\
\hline & & & & 0 \\
\hline & & & & \\
\hline & & & & \\
\hline & & & & \\
\hline & & & & \\
\hline & & & & \\
\hline & & & & \\
\hline & & & & \\
\hline & & & & \\
\hline & & & & \\
\hline & & & & \\
\hline
\end{tabular}




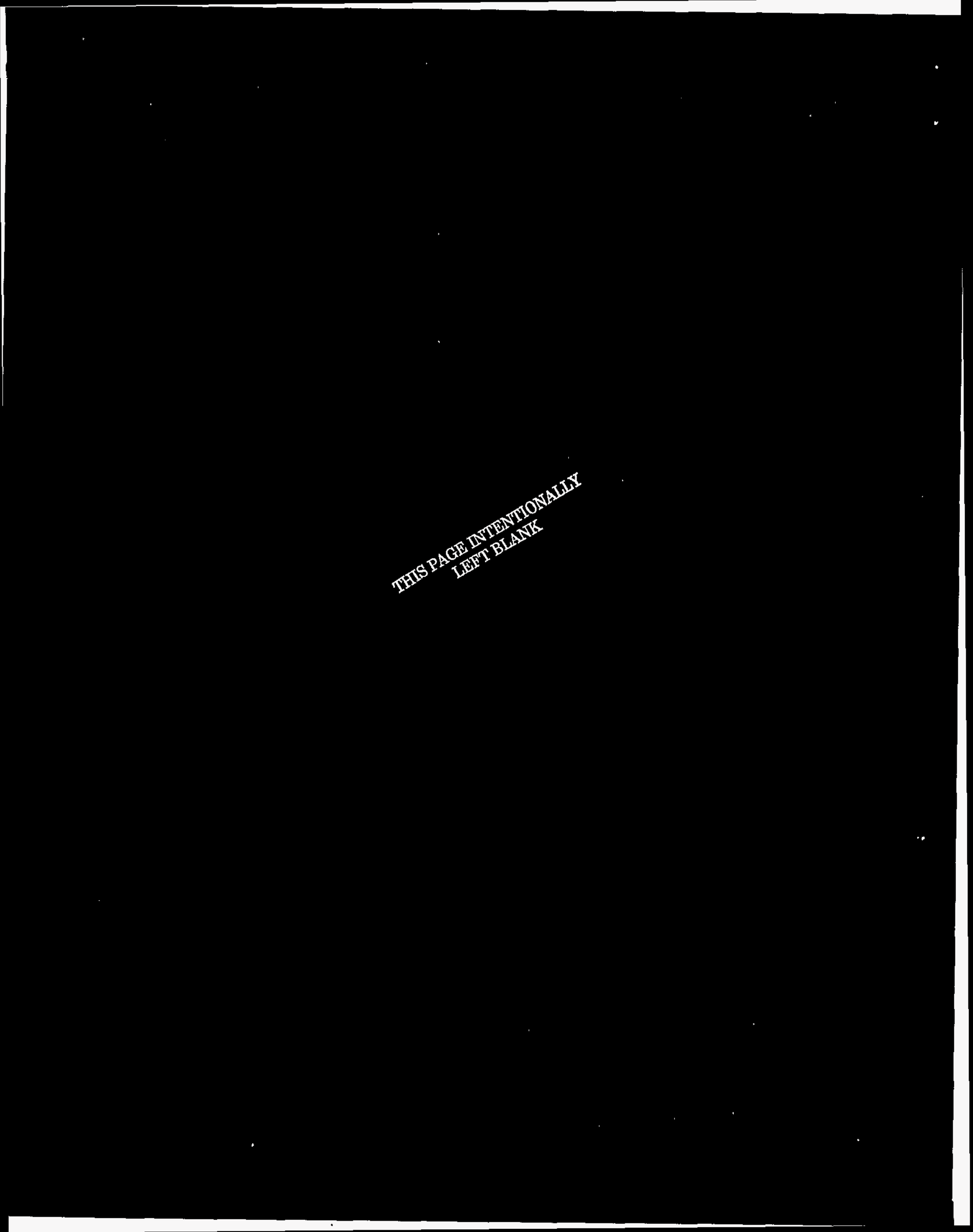




\title{
Tank 241-C-108 Headspace Gas and Vapor Characterization Results for Samples Collected in July 1993 and August 1994
}

\author{
J. L. Huckaby
}

Pacific Northwest Laboratories

D. R. Bratzel

Westinghouse Hanford Company

Date Published

September 1995

Prepared for the U.S. Department of Energy

Office of Environmental Restoration and

Waste Management

\footnotetext{
(2)

Westinghouse

Menagement and Operations Contractor for the

U.S. Department of Energy under Contract DE-ACO6-87FL.10930
} 



\section{Contents}

1.0 INTRODUCTION $\ldots \ldots \ldots \ldots \ldots \ldots \ldots \ldots \ldots \ldots \ldots \ldots \ldots \ldots \ldots \ldots \ldots \ldots \ldots \ldots \ldots$

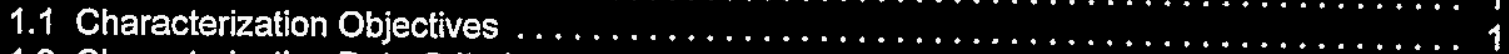

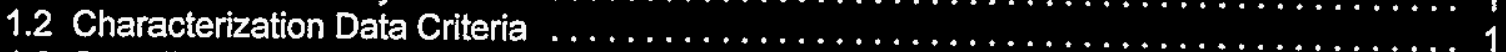

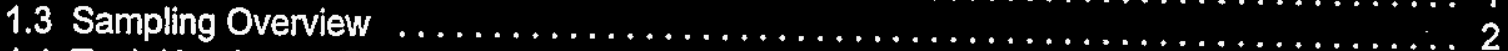

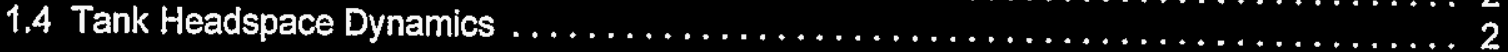

2.0 SAMPLING EVENT $\ldots \ldots \ldots \ldots \ldots \ldots \ldots \ldots \ldots \ldots \ldots \ldots \ldots \ldots \ldots \ldots \ldots \ldots \ldots$

2.1 July 1993 In Situ Sampling Event . . . . . . . . . . . . . . . . . . . . . . .

2.2 August 1994 Vapor Sampling System Sampling Event . . . . . . . . . . . . . . . . 3

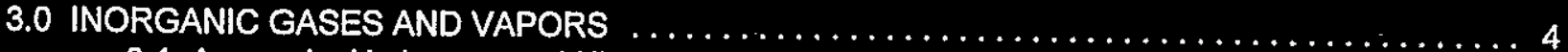

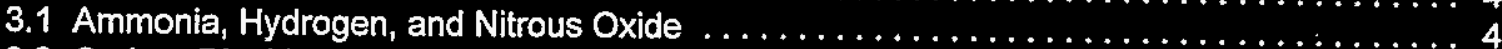

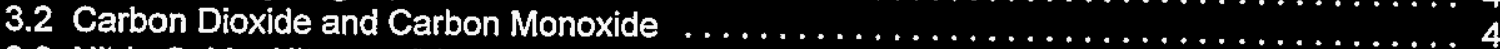

3.3 Nitric Oxide, Nitrogen Dioxide, Water and Tritium $\ldots \ldots \ldots \ldots \ldots \ldots \ldots \ldots \ldots \ldots$

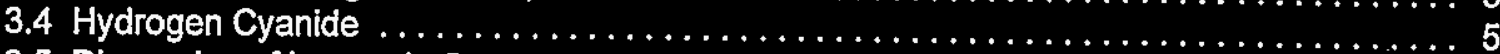

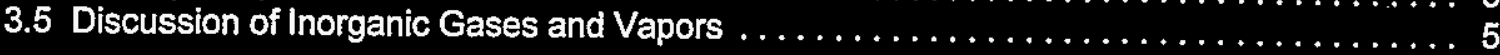

4.0 ORGANIC VAPORS $\ldots \ldots \ldots \ldots \ldots \ldots \ldots \ldots \ldots \ldots \ldots \ldots \ldots \ldots \ldots \ldots \ldots \ldots$

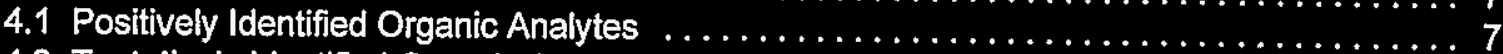

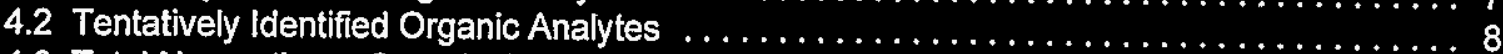

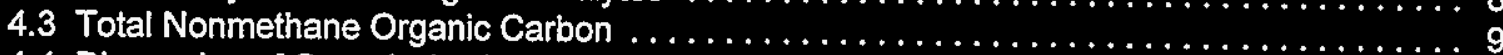

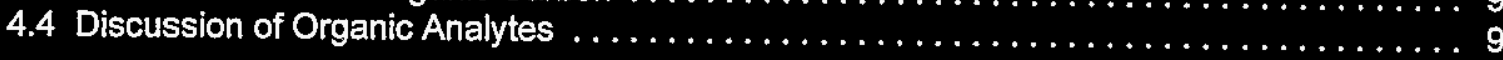

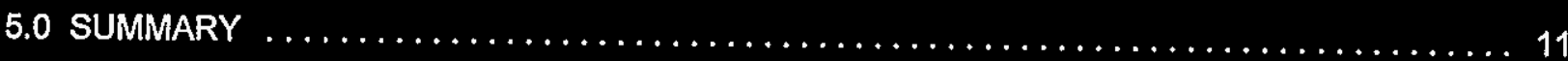

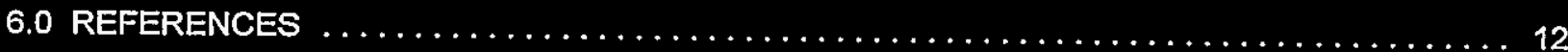

Acronyms and Abbreviations

$\begin{array}{ll}\text { CES } & \text { consensus exposure standard } \\ \text { EPA } & \text { Environmental Protection Agency } \\ \text { GC } & \text { gas chromatograph } \\ \text { GC/MS } & \text { gas chromatograph/mass spectrometer } \\ \text { ISS } & \text { in situ sampling } \\ \text { LFL } & \text { lower flammability limit } \\ \text { MS } & \text { mass spectrometer } \\ \text { NFPA } & \text { National Fire Protection Association } \\ \text { NPH } & \text { normal paraffinic hydrocarbon } \\ \text { OGIST } & \text { Oregon Graduate Institute of Science and Techinoiogy } \\ \text { ORNL } & \text { Oak Ridge National Laboratory } \\ \text { PNL } & \text { Pacific Northwest Laboratory } \\ \text { ppmv } & \text { parts per million by volume, } 1 \text { ppmv }=10^{-4} \text { vol\% } \\ \text { TNMOC } & \text { total nonmethane organic carbon } \\ \text { TST } & \text { triple sorbent trap } \\ \text { Vol\% } & \text { percent by volume, } 1 \text { vol\% }=10,000 \mathrm{ppmv} \\ \text { VSS } & \text { vapor sampling system } \\ \text { WHC } & \text { Westinghouse Hanford Company }\end{array}$


WHC-SD-WM-ER-423 Rev. 2

\section{Acknowledgements}

The authors wish to thank Chris Simonen for her work verifying data and generating tables, and Shas Mattigod for his help with the construction and reviews of this document. The authors also wish to thank Luther Buckley, Clarence Homi, and Tom Kunthara for their contributions to the final reviews and publication of this document. 
WHC-SD-WM-ER-423 Rev. 2

\title{
Tank 241-C-108 Headspace Gas and Vapor Characterization Results
}

\author{
for Samples Collected in July 1993 and August 1994
}

\subsection{INTRODUCTION}

\subsection{Characterization Objectives}

Tank C-108 headspace gas and vapor samples were collected and analyzed to help determine the potential risks of fugitive emissions to tank farm workers. The drivers and objectives of waste tank headspace sampling and analysis are discussed in Program Plan for the Resolution of Tank Vapor lssues (Osborne and Huckaby 1994). This report primarily discusses results from the August 1994 sampling event, but also includes selected results of the July 1993 sampling event. The tank C-108 headspace was sampled in July 1993 to address concerns about hydrogen cyanide fugitive emissions from the waste tanks (Saget 1992), and in August 1994 in accordance with Data Quality Objectives for Generic In-Tank Health and Safety Issue Resolution (Osborne et al. 1994).

\subsection{Characterization Data Criteria}

Data Quality Objectives for Generic In-Tank Health and Safety Issue Resolution describes parameters for data collection to ensure appropriate conclusions can be drawn from the data. Tank headspace characterization data were collected to help in the evaluation of 1) headspace flammability, and 2) identification and quantification of compounds of toxicological concern.

Single Shell Tank Interim Operational Safety Requirements (Dougherty 1995) specifies that combustible constituents in tank headspaces be maintained below $25 \%$ of the lower flammability limit (LFL). This essentially agrees with National Fire Protection Association requirements that combustible concentrations be maintained at or below $25 \%$ of the LFL (NFPA 1992). Current governing operating specifications for Watchlist tanks, such as tank $\mathrm{C}-108$, specify that combustible constituents be maintained at or below $20 \%$ of the LFL (WHC 1995a).

Headspace characterization data are used by Westinghouse Hanford Company (WHC) Tank Waste Remediation Systems Industrial Hygiene as source term data in the industrial hygiene strategy to protect workers from tank fugitive emissions. Because selection of worker protective equipment must be based on industrial hygiene monitoring of the work place and not on source term data (29 CFR 1910.120), tank headspace characterization data can not be used for this purpose. Furthermore, because there are mechanisms by which headspace constituents can be either diluted or concentrated as they are released to the atmosphere, the headspace characterization data should not be considered to be representative of emissions at the point of emission.

These statements notwithstanding, the data quality objectives document specifies that the industrial hygiene group be advised if constituents with toxicological properties exceed $50 \%$ of the appropriate consensus exposure standard (CES) for non-carcinogens, or $10 \%$ of the appropriate CES for carcinogens. A CES is defined as the most stringent of known regulatory or recommended toxicological values for the workplace (Osborne et al. 1994). 


\subsection{Sampling Overview}

Tank C-108 was vapor sampled in July 1993 and July 1994 using in situ sampling (ISS) methods. In the July 1993 sampling event, liquid-filled bubblers were lowered into the tank headspace to sample for hydrogen cyanide. The second ISS event, in July 1994, was performed as required by Safety Assessment for Gas Sampling All Ferrocyanide Tanks (Farley 1991). In the July 1994 event, sorbent traps lowered into the tank headspace were contaminated with radioactive particles, and could not be analyzed.

Tank C-108 was sampled again in August 1994 using the more robust Vapor Sampling System (VSS). Because there are discrepancies between resutts from the 1SS and VSS methods that are not understood (Huckaby 1994a), results from early ISS events are generally considered to be less valid than results from the VSS events. Nevertheless, a brief description of the July 1993 ISS event and the results of the hydrogen cyanide sampling are presented below, because this analyte was not sampled for during the VSS event. Huckaby et al. (1995) describe the bases for using the iss method for hydrogen cyanide, and why it was not sampled for during the VSS event. All other results presented here are from the August 1994 VSS sampling event.

Samples collected are thought to have been representative of the tank C-108 headspace when the tank was sampled, and sample analyses were designed to provide a reasonably accurate and complete characterization of the significant headspace constituents (Meacham et al. 1995). No assessment has been made of how the tank C-108 headspace composition changes with time, though studies of tank C103 suggest that composition changes probably occur very slowly in the passively ventilated tanks (Huckaby and Story 1994).

\subsection{Tank Headspace Dynamics}

Tank C-108 is the second tank in a 3-tank cascade with tanks $C-107$ and $C-109$, and is connected to both tanks $\mathrm{C}-107$ and $\mathrm{C}-109$ via $7.4-\mathrm{cm}(2.9-\mathrm{in}$.) inside diameter, 7.6-m (25-ft) long cascade lines. Since these cascade lines connect the headspaces of these tanks, gases and vapors originating from the wastes in tank $\mathrm{C}-107$ or tank $\mathrm{C}-109$ may be transferred to tank $\mathrm{C}-108$ (unless the cascade lines are obstructed). However, headspace data, as discussed in Section 3.5, indicate that the inter-tank exchange of gases and vapors has little effect on the headspace composition of tank C-108.

The cascade of tanks C-107, C-108, and C-109 is passively ventilated, which means that the tanks are allowed to exhale air, waste gases, and vapors as the barometric pressure falls, and inhale ambient air as the barometric pressure rises. Each of these tanks has its own filtered breather riser. Barometric pressure typically rises and falls on a diurnal cycle, producing an average daily exchange of air equal to about $0.46 \%$ of each tank headspace (Huckaby 1994b). Changes in the concentrations of tank headspace constituents due to barometric pressure changes are consequently very slow. 


\subsection{SAMPLING EVENT}

\subsection{July 1993 In Situ Sampling Event}

Tank C-108 was sampled using ISS methods on July 23, 1993 by WHC Sampling and Mobile

Laboratories. This sampling was conducted to address concerns that ferrocyanide Watch List tanks could be releasing hydrogen cyanide vapors into the breathing zone of tank farm workers (Saget 1992).

Samples for hydrogen cyanide were collected from a point approximately $7.8 \mathrm{~m}$ below the top of the flange on riser 3, between 2:00 p.m. and 3:30 p.m.

Huckaby et al. (1995) give a general description of the ISS method and equipment. Pingel (1993) provides field sampling information for the tank C-108 June 1993 ISS event. In addition to the hydrogen cyanide results presented below, Lerner and Pool (1994) provide sample preparation and analysis results for selected organic and inorganic vapors.

\subsection{August 1994 Vapor Sampling System Sampling Event}

Headspace gas and vapor samples were collected from tank C-108 using the VSS on August 5, 1994 by WHC Sampling and Mobile Laboratories (WHC 1995b). Sample collection and analysis were performed as directed by the sample and analysis plan' (WHC 1995b, Appendix A). The tank headspace temperature was determined to be $25^{\circ} \mathrm{C}$. Air from the tank $\mathrm{C}-108$ headspace was withdrawn via a $7.9 \mathrm{~m}$ long heated sampling probe mounted in riser 4 , and transferred via heated tubing to the VSS sampling manifold. All heated zones of the VSS were maintained at approximately $50^{\circ} \mathrm{C}$.

Sampling media were prepared and analyzed by WHC, Oak Ridge National Laboratories (ORNL), Pacific Northwest Laboratories (PNL), and Oregon Graduate Institute of Science and Technology (OGIST) through a contract with Sandia National Laboratories. The 39 tank air samples and 2 ambient air control samples collected are listed in Table 2-1 by analytical laboratory. Table 2-1 also lists the 18 trip blanks provided by the laboratories.

A general description of vapor sampling and sample analysis methods is given by Huckaby et al. (1995). The sampling equipment, sample collection sequence, sorbent trap sample air flow rates and flow times, chain of custody information, and a discussion of the sampling event itself are given in WHC (1995b).

The current requirement that sampling and analysis parameters be specified by a tank characterization plan was not in effect for gas and vapor sampling until October 1, 1994. 


\subsection{INORGANIC GASES AND VAPORS}

Analytical results of sorbent trap and SUMMA ${ }^{\mathrm{TM}, 2}$ canister tank air samples for selected inorganic gases and vapors are given in Table 3-1 in parts per million by volume (ppmv) in dry air. The concentration of water vapor given in Table 3-1 has been adjusted to tank conditions and are given in Section 3.3. Inorganic analyte sorbent traps were prepared and analyzed by PNL. All PNL results were produced at PNL quality assurance impact level 3. SUMMA'M canister samples were prepared and analyzed by OGIST. OGIST was not operating under a WHC-approved quality assurance plan when samples were analyzed, so OGIST data have been placed in square brackets both in Table 3-1 and elsewhere in the report to indicate that they represent secondary results. Reports by Lucke et al. (1995) and Rasmussen (1994) describe sample preparation and analyses.

OGIST SUMMA ${ }^{\text {TM }}$ canister analyses were began 14 days after the samples were collected, PNL analyses of the ISS hydrogen cyanide samples was performed 6 days after these samples were collected, and all PNL inorganic vapor sorbent traps from the VSS sampling event were performed within 14 days after sample collection (Rasmussen 1994, Ligotke 1995). The 60-day holding time requirement of the WHC quality assurance project plan (Keller 1994) was consequently satisfied. The 60-day holding time was administratively chosen, and no holding time study has been done to address the stability of analytes in SUMMA ${ }^{\mathrm{TM}}$ canisters in the chemical matrix of tank samples.

\subsection{Ammonia, Hydrogen, and Nitrous Oxide}

Ammonia concentration in the headspace of tank C-108 was determined to be 2.7 ppmv. This is the lowest ammonia concentration measured in any passively ventilated tank. The relatively low ammonia concentration in tank C-108 may be related to the fact that only a small quantity of relatively cool waste is stored in tank C-108. Given the LFL of ammonia in air is about 15 by volume (vol\%), the measured 2.7 ppmv corresponds to about $0.002 \%$ of the LFL, and does not contribute appreciably to the flammability of the headspace.

The tank C-108 hydrogen concentration was measured to be an average [15.3 ppmv] in 3 OGIST SUMMA ${ }^{T M}$ samples. In general, hydrogen is of concern as a fuel. The measured [15.3 ppmv] of hydrogen in tank C-108, however, represents only about $0.04 \%$ of the LFL for hydrogen in air, and is not a flammability concern at this level.

Nitrous oxide was measured to be present in the 3 OGIST SUMMA ${ }^{\mathrm{TM}}$ samples at an average [344 ppmv]. This is higher than has typically been measured in other passively ventilated tanks that have been sampled, but higher values have also been measured. Under the proper conditions, nitrous oxide can serve as an oxidizer to support combustion. However, Cashdollar et al. (1992) found that nitrous oxide had no significant effect on the flammability of hydrogen and air mixtures for hydrogen concentrations less than 20 vol\%, and that "small amounts of nitrous oxide (relative to air) do not appear to have much effect on the flammability". Their results suggest the measured nitrous oxide concentration is much too low to have a significant effect on the flammability of the tank C-108 headspace.

\subsection{Carbon Dioxide and Carbon Monoxide}

2 SUMMA is a trademark of Molectrics, Inc., Cleveland, Ohio. 
The average measured headspace carbon dioxide concentration, [16.3 ppmv], is markedly lower than normal ambient air concentrations. In ambient air carbon dioxide is typically present at 350 to 400 ppmv, and typically lower than this in the waste tank headspaces. Carbon dioxide introduced by air exchange with the atmosphere is readily absorbed by caustic supernatant and interstitial liquids of the waste tanks, and converted to carbonate in solution.

Carbon monoxide in the tank C-108 headspace, at about [0.10 ppmv], is about the same as in ambient air, where it typically ranges from 0.05 to $0.15 \mathrm{ppmv}$. Elevated waste tank headspace carbon monoxide concentrations are common (e.g., carbon monoxide concentration ${ }^{3}$ in tank C-103 was [26.7 ppmv], Huckaby and Story 1994), and are thought to be due to the decomposition of organic waste in the tanks. The relatively low carbon monoxide in tank C-108 may be due to the fact that the tank has a relatively small, cool waste inventory.

\subsection{Nitric Oxide, Nitrogen Dioxide, Water and Tritium}

Nitric oxide and nitrogen dioxide concentrations in the tank C-108 headspace were determined to be 0.24 ppmv and $\leq 0.04$ ppmv, respectively. These are both acid gases that would have very low equilibrium concentrations above the high pH sludge in tank $\mathrm{C}-108$. The measurable presence of nitric oxide may be due to its formation from oxygen and nitrogen in the radiation field of the headspace. These constituents could potentially serve as oxidizers to support combustion, but at the measured concentrations would have a negligible effect on the flammability of the tank C-108 headspace.

The water vapor concentration of tank $\mathrm{C}-108$ was determined to be about $17.5 \mathrm{mg} / \mathrm{L}$, at the tank headspace temperature of $25^{\circ} \mathrm{C}$ and pressure of 990 mbar (743 torr), (WHC 1995b). This corresponds to water vapor partial pressure of $24.1 \mathrm{mbar}$ ( 18.1 torr), to a dew point of $20.5^{\circ} \mathrm{C}$, and to a relative humidity of $76 \%$.

Silica gel sorbent traps were used to test for tritium. It is assumed that tritium produced by the waste combines with hydroxide ions to form tritium-substituted water. Evaporation of the tritium-substituted water would then result in airborne radioactive contamination. Silica gel sorbent traps adsorb virtually all (normal and tritium-substituted) water vapor from the sampled tank air, and are analyzed at the WHC 222$S$ laboratory. Radiochemical analysis of the silica gel trap indicated the total activity of the headspace to be less than 50 pCi/L (WHC 1995b).

\subsection{Hydrogen Cyanide}

Analysis of the liquid-filled bubblers for hydrogen cyanide indicated the concentration of this analyte to be below 0.0003 ppmv in all 3 samples. The absence of hydrogen cyanide at measurable concentrations is consistent with the expectation that an acid gas, such as hydrogen cyanide, wouid not exist at significant concentrations above the caustic waste in tank $\mathrm{C}-108$. No hydrogen cyanide has been detected in any of the 10 waste tank headspaces sampled for this analyte.

\subsection{Discussion of Inorganic Gases and Vapors}

\footnotetext{
${ }^{3}$ The carbon monoxide measurement in tank C-103 was made by OGIST, and should be considered secondary data.
} 


\section{WHC-SD-WM-ER-423 Rev. 2}

Aside from water vapor, the most abundant waste constituent in the tank $\mathrm{C}-108$ headspace is nitrous oxide. Nitrous oxide, ammonia, and hydrogen have been detected in most tank headspaces sampled to date and are usually the dominate waste species. The concentration of nitrous oxide in tank C-108 is above the average for other tanks that have been sampled, but the hydrogen concentration in tank C-108 is relatively low, and the ammonia concentration is very low.

The small relative standard deviations of the results, given in the last column in Table 3-1, indicate the precision of reported results is good. Relative standard deviations range from $0.3 \%$ for nitrous oxide results, to $30 \%$ for carbon monoxide results. The larger relative standard deviation of the carbon monoxide results is due to the fact that it is near the analytical method's limit of quantitation. The precision reported depends both on sampling parameters (e.g., sample flow rate and flow time for sorbent traps) and analytical parameters (e.g., sample preparation, dilutions, etc.), and the small relative standard deviations suggest a high degree of control was maintained both in the field and in the laboratories.

As discussed briefly in Section 1.3, it is possible that gases and vapors generated by the waste in tanks C107 and C-109 could be transferred to tank C-108 via the cascade lines. Table 3-2 lists the measured concentrations of selected inorganic gases and vapors in tanks C-107, C-108, and C-109. If a significant exchange of gases and vapors were taking place between adjacent tanks, either their headspace compositions would be very similar, or all constituents detected in one tank would be at equal or higher concentration in the other tank. Consideration of the data in Table 3-2 indicates that any transfer of gases and vapors between these tanks is probably negligible. Specifically, hydrogen is at much higher concentrations in tanks C-107 and C-109 than in tank C-108, and nitrous oxide is at a much higher concentration in tank C-108 than in tank C-107. 
WHC-SD-WM-ER-423 ReV. 2

\subsection{ORGANIC VAPORS}

Organic vapors in the tank C-108 headspace were sampled using SUMMA ${ }^{\mathrm{TM}}$ canisters, which were analyzed by PNL, and triple sorbent traps (TSTs), which were analyzed by ORNL. Both PNL and ORNL used a gas chromatograph (GC) equipped with a mass spectrometer (MS) detector to separate, ideñtify, and quantitate the analytes. Descriptions of sample device cleaning, sample preparations, and analyses are given by Jenkins et al. (1994) and Lucke et al. (1995). Quantitative measurements of the methane concentration and the total nonmethane organic carbon (TNMOC) concentration by the U.S. Environmental Protection Agency (EPA) task order 12 (TO-12) method were also performed by OGIST (EPA 1988, Rasmussen 1994).

SUMMA ${ }^{\mathrm{TM}}$ sample results should be considered to be the primary organic vapor data for tank $\mathrm{C}-108$. PNL results were produced at PNL quality assurance impact level 3 . PNL SUMMA ${ }^{\text {TM }}$ analyses were not completed until 62 days after sample collection. This exceeded the administratively chosen 60-day holding time (Keller 1994). No holding time study has been performed to determine the stability of analytes in SUMMA ${ }^{\mathrm{TM}}$ canisters in the chemical matrix of the tank samples.

ORNL analyses of TST samples from this and other waste tanks generally agree with, support, and augment the SUMMA ${ }^{T M}$ sample results. However, because certain WHC quality assurance requirements were not satisfied by ORNL, the quality assurance assessment of ORNL by Hendrickson (1995) should be reviewed before results unique to the TST samples are used for decision making. Similarly, the OGIST methane and TNMOC measurements were conducted in the absence of a WHC-approved quality assurance project plan, and should be considered secondary data.

All TSTs prepared by ORNL had 3 surrogate compounds added to evaluate sample matrix effects, potential handling, storage, and shipment problems, and analytical instrumentation performance (Jenkins et al. 1995a). ORNL evaluated the surrogate recoveries using a statistical approach similar to that prescribed by SW 846 Method 8260 A Volatile Organic Compounds by Gas Chromatography/Mass Spectrometry (GCMMS) Capillary Column Technique (EPA 1992). Using this approach, ORNL. reported that all surrogates had standard deviation values within the $95 \%$ confidence interval for variance, indicating that no bias was introduced in the measurement of analyte quantities (Jenkins 1995a).

\subsection{Positively Identified Organic Analytes}

Positive identification of organic analytes using the methods employed by PNL and ORNL involves matching the GC retention times and MS data from a sample with that obtained by analysis of standards. The concentration of an analyte in the sample is said to be quantitatively measured if the response of the GC/MS has been established at several known concentrations of that analyte (i.e., the GC/MS has been calibrated for that analyte), and the MS response to the analyte in the sample is between the lowest and highest responses to the known concentrations (i.e., the analyte is within the calibration range).

ORNL and PNL were assigned different lists of organic compounds, or target analytes, to positively identify and measure quantitatively. The ORNL target analyte list was derived from a review of the tank C103 headspace constituents by a panel of toxicology experts (Mahlum et al. 1994). The PNL target analyte list included 40 compounds in the Environmental Protection Agency (EPA) task order 14 (TO-14) method, which are primarily halocarbons and common industrial solvents (EPA 1988), plus 14 analytes selected mainly from the toxicology panel's review of vapor data on tank C-103. 
Given in Table 4-1 are the organic compounds positively identified and quantitated in SUMMA ${ }^{\mathrm{TM}}$ canister samples by PNL and OGIST. PNL performed analyses according to the EPA TO-14 methodology (EPA 1988, Lucke et al. 1995). Only 2 of the 40 TO-14 analytes were observed to be above the 0.002 ppmv quantitation limit of the analyses, and 1 of these analytes, 1,1,2-trichloro-1,2,2-trifluoroethane, is thought to be a contaminant of analysis (Lucke et al. 1995). The results for methane are those of OCIST

(Rasmussen 1994). Averages reported are from analyses of 3 SUMMA ${ }^{\text {TM }}$ canister samples except where noted.

Jenkins et al. (1995a) report the positive identification of 17 of 27 analytes in TST samples. Despite calibration of the instrument over a 20-fold concentration range, only 1 analyte was quantitated in all 5 of the TST samples. All positively identified analytes, and their average concentrations from the analysis of 5 TSTs, are given in Tables 4-2, 4-3, and 4-4. Table 4-2 lists the single positively identified, quantitated analyte, Table 4-3 lists the positively identified analytes which were not quantitated (because the measurement was outside the calibration range for at least 1 sample), and Table 4-3 lists the single positively identified analyte which exceeded its practical holding time. Tables 4-2, 4-3, and 4-4 are mutually exclusive, so that no analyte appears in more than 1 of these tables. Data in Tables 4-3 and 4-4 should not be considered quantitative and may not be accurate to within $\pm 30 \%$ as specified by Burnum (1995).

The ORNL practical holding time is defined as the holding time for which there is a $15 \%$ risk that the concentration of an analyte in the sample will be below its initial concentration. As indicated in Table 4-4, 1-butanol exceeded its practical holding time, and may have been affected by the 25 day period between sample collection and analysis. Jenkins et al. (1995b) describe the ORNL practical holding time study, and report the practical holding time of 1-butanol is 17 days. It should be noted that the contractual holding time for the TST samples was 60 days.

Three target analytes were common to both the ORNL and PNL analyses: Dichloromethane, benzene, and toluene. The PNL and ORNL results for these analytes are given Table 4-5 for comparison. Neither ORNL nor PNL detected dichloromethane. ORNL detected trace amounts of benzene and toluene, but these were both below the 0.002 ppmv limit of detection of PNL.

The 2 most abundant analytes in Tables 4-1 through 4-4 are methane and propanone. At 0.32 ppmv, the methane concentration in tank $\mathrm{C}-111$ is at about the level it is in ambient air, and does not present a flammability risk. Similarly, propanone, at 0.018 ppmv, presents no flammability risks.

\subsection{Tentatively Identified Organic Analytes}

In addition to the target analytes, the ORNL and PNL analytical procedures allow the tentative identification of other organic compounds. Tentative identification of analytes was performed by comparing the MS molecular fragmentation patterns with a library of known MS fragmentation patterns. This method allows an organic analyte to be identified (with reasonable certainty) as an alkane, a ketone, an aldehyde, etc., and may also determine its molecular weight. The method usually does not, however, allow the unambiguous identification of structural isomers, and this ambiguity increases with analyte molecular weight. Using this method, many analytes can be tentatively identified with reasonable contidence without having to inject standards of each into the GC/MS to determine their GC retention times or specific MS patterns.

By the nature of the sampling devices, virtually all organic vapors present in the tank headspace are collected by both TST and SUMMA ${ }^{\mathrm{TM}}$ samples. Analyses of the samples are designed to recover, 
separate, and identify the organic vapors in the samples. TSTs are not good for collecting highly volatile compounds (i.e., molecules more volatile than propane), but are quite good for most others. In contrast, the recovery of very low volatility compounds (e.g., molecules with more than about 15 carbon atoms) and some polar compounds with moderate volatility (e.g., butanal) from SUMMA ${ }^{\text {TM }}$ samples has been problematic.

The PNL list of tentatively identified compounds, with estimated concentrations, is given in Table 4-6, and the ORNL list of tentatively identified compounds, and their estimated concentrations, is given in Table 47. Because the list of tentatively identified organic compounds in TST samples is long and finding any given compound may be difficult, the list has been sorted alphanumerically by compound name in Table 48. Table 4-9 gives the same list, sorted in order of decreasing estimated concentration. Numbers in the first columns of Tables 4-8 and 4-9 (Cmpd \#) identify the location of the compound in Table 4-7.

Estimated concentrations given in Tables $4-6$ through $4-9$ are in $\mathrm{mg} / \mathrm{m}^{3}$, based on dry air at $0{ }^{\circ} \mathrm{C}$ and 1.01 bar.

The PNL and ORNL methods used to tentatively identify and estimate concentrations are described by Jenkins et al. (1994) and Lucke et al. (1995), respectively, and should be reviewed before this data are used for decision making. Results in Tables 4-6 through 4-9 are presented in terms of observed peaks, and are not adjusted for the occurrence of split chromatographic peaks (e.g., Cmpd \# 30 and 32 in Table 4-7). In these instances, the estimated concentration of a compound appearing as a doublet or triplet is simply the sum of the individual peak estimates.

Concentrations given in Tables 4-6 and 4-7 should be considered rough estimates. The proper quantitation of all observed analytes is outside the scope and budget of these analyses, and the estimation of concentrations involves several important assumptions. The validity of each assumption depends on the analyte, and such factors as the specific configuration of the analytical instrumentation.

\subsection{Total Nonmethane Organic Carbon}

OGIST measured the TNMOC concentration in 3 SUMMA ${ }^{\text {TM }}$ canister samples using the EPA TO-12 method (Rasmussen 1994). The sample mean was $\left[0.35 \mathrm{mg} / \mathrm{m}^{3}\right]$, with a standard deviation of $[0.02$ $\mathrm{mg} / \mathrm{m}^{3}$ ]. The TNMOC is very low in tank $\mathrm{C}-108$ compared to other tanks that have been sampled. For comparison, the TNMOC concentration in clean ambient air may range from 0.030 to $0.100 \mathrm{mg} / \mathrm{m}^{3}$.

\subsection{Discussion of Organic Analytes}

Some of the compounds listed in Tables 4-1 through 4-7 were introduced to the tank with process waste streams, and are detected in the headspace because the original inventory has not been completely evaporated or degraded. Examples of these are tributyi phosphate, which was used as an extractant in several Hanford processes; dibutyl butylphosphonate, which was a contaminant of tributyl phosphate; and the semivolatile normal paraffinic hydrocarbons (NPHs), (i.e., n-undecane, n-dodecane, n-tridecane, and n-pentadecane) that were used as diluents of tributyl phosphate. Notably absent from the tank C-108 headspace are the semivolatile cyclic alkanes (e.g., methylated decahydronaphthalenes, cyclopentanes, and cyclohexanes) that have been associated with the NPHs in the 241-BY tank farm and several of the tanks in 241-C farm.

Most of the compounds in Tables 4-1 through 4-9 are believed to be chemical reaction and radiolytic reaction products of the semivolatile or nonvolatile organic waste stored in the tank. For example, 1- 
butanol is known to be formed by the hydrolysis of tributyl phosphate, and it has been suggested that the alcohols, aldehydes, ketones, nitriles, alkenes, and short chain alkanes are all degradation products of NPHs.

Examination of the compounds listed in Tables 4-1 through 4-9 suggests many of the volatile species (presumed to be degradation products of the NPHs) have functional groups on the molecule's first or second carbon atom. For example, most alkenes listed have their double bond between the first and second carbon atoms, and ketones generally have the double bonded oxygen atom on the second carbon atom.

Though their concentrations are not significant, many alcohols and acids were tentatively identified by ORNL (Tables 4-7 and 4-8). These have generally not been observed to be as numerous in other NPHrich tank headspaces, which tend to be dominated by aldehydes, ketones, and alkenes. 


\subsection{SUMMARY}

The tank C-108 headspace was sampled in July 1993 and August 1994 for gases and vapors to address flammability and industrial hygiene concerns. Results unique to the July 1993 event and essentially all results from the August 1994 event have been reported. It was determined that no headspace constituents exceeded the flammability or industrial hygiene notification limits specified in the current Vapor Sampling and Analysis Plan (Homi 1995). 
MIIS PAGE INIENTIONATLY LEEII BLANK 
WHC-SD-WM-ER-423 Rev. 2

\subsection{REFERENCES}

29 CFR 1910.120, 1993, "Hazardous Waste Operations and Emergency Response", Code of Federal Regulations.

Burnum, S. T., 1995, Qualification of Reported WHC Vapor Program Data, (letter 95-CHD-065 to president, Westinghouse Hanford Company, August 18), Department of Energy, Richland Operations Office, Richland, Washington.

Cashdollar, K. L., M. Hertzberg, I. A. Zlochower, C. E. Lucci, G. M. Green, and R. A. Thomas, 1992 , Laboratory Flammability Studies of Mixtures of Hydrogen, Nitrous Oxide, and Air, WHC-SD-WMES-219 Rev. 0, Westinghouse Hanford Company, Richland, Washington.

Dougherty, L. F., 1995, Single Shell Tank Interim Operational Safety Requirements, WHC-SD-WM-OSR005 Rev. 0, Westinghouse Hanford Company, Richland, Washington.

EPA 1988, Compendium of Methods for the Determination of Toxic Organic Compounds in Ambient Air, PB90-127374, U.S. Environmental Protection Agency, Washington, D.C.

EPA 1992, Test Methods for Evaluating Solid Waste, SW-846 Rev. 1, U.S. Environmental Protection Agency, Washington, D.C.

Farley, W. G., 1991, Safety Assessment for Gas Sampling All Ferrocyanide Tanks, WHC-SD-WM-SAD009 Rev. 2, Westinghouse Hanford Company, Richland, Washington.

Hendrickson, R. W., 1995, Tank Vapor Characterization Oak Ridge National Laboratories Quality Assurance Assessment, TWRSQA-95-0012, Westinghouse Hanford Company, Richland, Washington.

Homi, C. S., 1995, Vapor Sampling and Analysis Plan, WHC-SD-WM-TP-335 Rev. OG, Westinghouse Hanford Company, Richland, Washington.

Huckaby, J. L., 1994a, Vapor Sampling System (VSS) and In Situ Sampling (ISS) Method Comparison, WHC-SD-WM-RPT-101 Rev. 0, Westinghouse Hanford Company, Richland, Washington.

Huckaby, J. L., 1994b, Tank 241-C-103 Headspace Flammability, WHC-EP-0734 Rev. 1, Westinghouse Hanford Company, Richland, Washington.

Huckaby, J. L., 1995a, Tank 241-C-107 Headspace Gas and Vapor Characterization Results for Samples Collected in September 1994, WHC-SD-WM-ER-464 Rev. 1, Westinghouse Hanford Company, Richland, Washington.

Huckaby, J. L., 1995b, Tank 241-C-109 Headspace Gas and Vapor Characterization Results for Samples Collected in August 1994, WHC-SD-WM-ER-424 Rev. 2, Westinghouse Hanford Company, Richland, Washington.

Huckaby, J. L., and M. S. Story, 1994, Vapor Characterization of Tank 241-C-103, WHC-EP-0780 Rev. 0, Westinghouse Hanford Company, Richland, Washington. 
WHC-SD-WM-ER-423 ReV. 2

Huckaby, J. L., H. Babad, and D. R. Bratzel, 1995, Headspace Gas and Vapor Characterization Summary for the 43 Vapor Program Suspect Tanks, WHC-SD-WM-ER-514 Rev. 0, Westinghouse Hanford Company, Richland, Washington.

Jenkins, R. A., 1995a, Untitled, (Letter 090195A to D. Bratzel, September 1), Oak Ridge National Laboratory, Oak Ridge, Tennessee.

Jenkins, R. A., 1995b, Untitled, (Letter 091495 A to D. Bratzel, September 14), Oak Ridge National Laboratory, Oak Ridge, Tennessee.

Jenkins, R. A, A. B. Dindal, C. E. Higgins, C. Y. Ma, and J. T. Skeen, 1994, Analysis of Tank 241-C-108 Headspace Components, Oak Ridge National Laboratory, Oak Ridge, Tennessee.

Jenkins, R. A, A. B. Dindal, C. Y. Ma, M. A. Palausky, J. T. Skeen, and C. K. Bayne, 1995, Analysis of Tank 241-TY-104 Headspace Components, ORNL-CASD-FR-241TY104.95 Rev, 1, Oak Ridge National Laboratory, Oak Ridge, Tennessee.

Keller, K. K., 1994, Quality Assurance Project Plan for Tank Vapor Characterization, WHC-SD-WMQAPP-013 Rev. 2, Westinghouse Hanford Company, Richland, Washington.

Lemer, B. D. and K. H. Pool, 1994, Waste Tank Safety Program Annual Status Report for FY 1993 Task 4: Innorganic Chemistry, PNL-8979-4 UC-601 UC-606 UC-607, Pacific Northwest Laboratory, Richland, Washington.

Ligotke, M. W. 1995, PNL Vapor Project Analytical Holding Times, (Letter to D. R. Bratzel, September 23), Pacific Northwest Laboratory, Richland, Washington.

Lucke, R. B., M. W. Ligotke, K. H. Pool, T. W. Clauss, A. K. Sharma, B. D. MoVeety, M. McCulloch, J. S. Fruchter, and S. C. Goheen, 1995, Vapor Space Characterization of Waste Tank 241-C-108: Results from Samples Collected Through the Vapor Sampling System on 8/5/94, PNL-10351UC606, Pacific Northwest Laboratory, Richland, Washington.

Mahlum, D. D., J. Y. Young, and R. E. Weller, 1994, Toxicologic Evaluation of Analytes from Tank 231-C103, PNL-10189, Pacific Northwest Laboratory, Richland, Washington.

Meacham, J. E., H. Babad, R. J. Cash, G. T. Dukelow, S. J. Eberlein, D. W. Hamilton, G. D. Johnson, J. W. Osborne, M. A. Payne, D. J. Sherwood, D. A. Turner, and J. L. Huckaby, 1995, Approach for Tank Safety Characterization of Hanford Site Waste, WHC-EP-0843 Rev. 0, UC-2070, Westinghouse Hanford Company, Richland, Washington.

NFPA 1992, Standard on Explosion Prevention Systems, NFPA 69, National Fire Protection Association, Quincy, Massachusetts.

Osborne, J. W., and J. L. Huckaby, 1994, Program Plan for the Resolution of Tank Vapor Issues, WHCEP-0562 Rev. 1, Westinghouse Hanford Company, Richland, Washington.

Osborne, J. W., J. L. Huckaby, T. P. Rudolph, E. R. Hewitt, D. D. Mahlum, J. Y. Young, C. M. Anderson, 1994, Data Quality Objectives for Generic In-Tank Health and Safety Issue Resolution, WHC-SDWM-DQO-002, Westinghouse Hanford Company, Richland, Washington. 
Pingel, L. A., 1993, Results from the Vapor Sampling of Waste Tank C-108, 12920-SAS93-060, Westinghouse Hanford Company, Richland, Washington.

Rasmussen, R. A., 1994, Oregon Graduate Institute Vapor Analysis Results, Tank 241-C-108, August 1 994, Oregon Graduate Institute of Science and Technology, Beaverton, Oregon.

Saget, R. P., 1992, Hydrogen Cyanide Off-Gassing form Ferrocyanide Waste Tanks, (Letter 9200668 to president, Westinghouse Hanford Company, January 29), Department of Energy, Richland Operations Office, Richland, Washington.

WHC 1995a, Operating Specifications for Watchlist Tanks, OSD-T-151-00030 Rev. B-9, Westinghouse Hanford Company, Richland, Washington.

WHC 1995b, Vapor and Gas Sampling of Single-Shell Tank 241-C-108 Using the Vapor Sampling System, WHC-SD-WM-RPT-110, Westinghouse Hanford Company, Richland, Washington. 


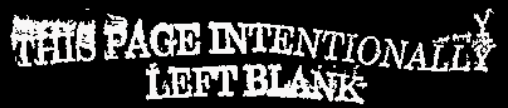


WHC-SD-WM-ER-423 Rev. 2

Table 2-1

Tank C-108 Gas and Vapor Sample Type and Number for August 1994 Sampling Event

\begin{tabular}{|c|c|c|c|c|}
\hline Laboratory & Sampling Device & $\begin{array}{c}\text { Nominal Sample } \\
\text { Volume (L) }\end{array}$ & Target Analytes & Number of Samples \\
\hline $\begin{array}{l}\text { Oak Ridge National } \\
\text { Laboratories }\end{array}$ & Triple Sorbent Trap & $\begin{array}{l}2.0 \\
4.0\end{array}$ & $\begin{array}{l}\text { Organic vapors } \\
\text { Organic vapors }\end{array}$ & $\begin{array}{l}4 \text { tank air samples } \\
4 \text { tank air samples } \\
+6 \text { trip blanks }\end{array}$ \\
\hline $\begin{array}{l}\text { Oregon Graduate Institute of } \\
\text { Science and Technology }\end{array}$ & $\begin{array}{l}\text { SUMMA }^{\mathrm{TM}} \text { canister } \\
.\end{array}$ & 6.0 & $\begin{array}{l}\text { Hydrogen, } \\
\text { Nitrous Oxide, Carbon } \\
\text { Dioxide, Carbon } \\
\text { Monoxide }\end{array}$ & 3 tank air samples \\
\hline \multirow[t]{5}{*}{$\begin{array}{l}\text { Pacific Northwest } \\
\text { Laboratories }\end{array}$} & Acidified Carbon Sorbent Trap & 3.0 & Ammonia & $\begin{array}{l}6 \text { tank air samples } \\
+3 \text { trip blanks }\end{array}$ \\
\hline & Triethanolamine Sorbent Trap & 3.0 & Nitrogen Dioxide & $\begin{array}{l}6 \text { tank air samples } \\
+3 \text { trip blanks }\end{array}$ \\
\hline & $\begin{array}{l}\text { Oxidation bed }+ \\
\text { Triethanolamine Sorbent Trap }\end{array}$ & 3.0 & Nitric Oxide & $\begin{array}{l}6 \text { tank air samples } \\
+3 \text { trip blanks }\end{array}$ \\
\hline & Silica Gel Sorbent Trap & 3.0 & Water vapor & $\begin{array}{l}6 \text { tank air samples } \\
+3 \text { trip blanks }\end{array}$ \\
\hline & SUMMA ${ }^{\mathrm{TM}}$ canister & 6.0 & Organic vapors & $\begin{array}{l}3 \text { tank air samples } \\
+2 \text { ambient air samples }\end{array}$ \\
\hline WHC 222-S Laboratory & Silica Gel Sorbent Trap & 1.0 & $\begin{array}{l}\text { Tritium-Substituted Water } \\
\text { Vapor }\end{array}$ & 1 tank air sample \\
\hline
\end{tabular}




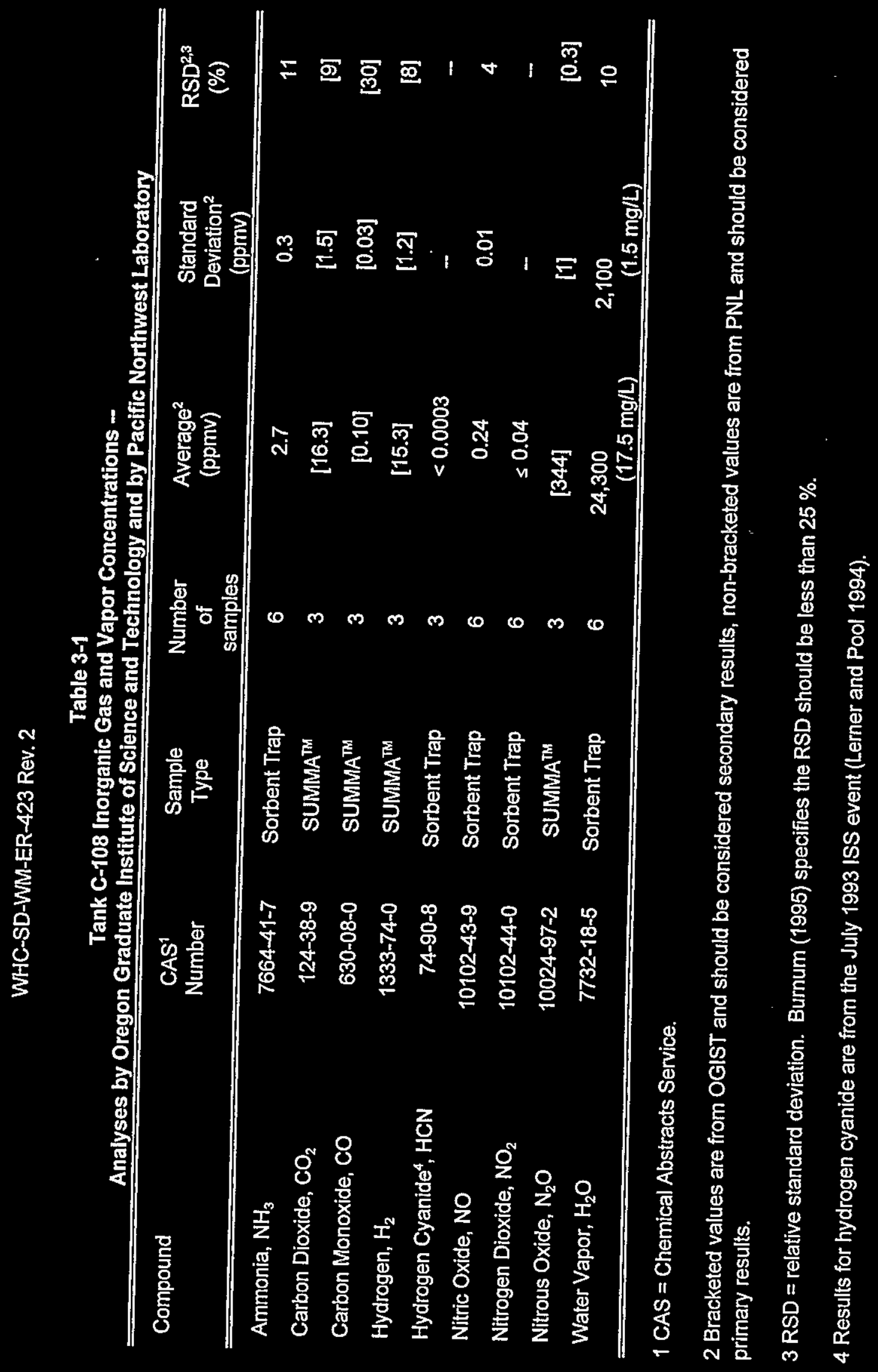


Table 3-2

Comparison of Tank C-107, C-108, and C-109 Headspace Constituents Inorganic Analyses by Oregon Graduate Institute of Science and Technology, and Organic Analyses by Oak Ridge National Laboratory ${ }^{1}$

\begin{tabular}{lccc}
\hline \hline Tank: & C-107 & C-108 & C-109 \\
\hline \hline Date sampled, (mo/day/yr) & $9 / 9 / 94$ & $8 / 5 / 94$ & $8 / 10 / 94$ \\
\hline Headspace temperature, $\left({ }^{\circ} \mathrm{C}\right)$ & 45.9 & 25 & 27 \\
\hline Ammonia, (ppmv) & 84 & 2.7 & 10.1 \\
Hydrogen, (ppmv) & {$[230]$} & {$[15.3]$} & {$[125]$} \\
Carbon dioxide, (ppmv) & {$[725]$} & {$[16.3]$} & {$[3]$} \\
Carbon monoxide, (ppmv) & {$[1.7]$} & {$[0.10]$} & {$[0.41]$} \\
Nitric oxide, (ppmv) & 0.20 & 0.24 & 0.51 \\
Nitrogen dioxide, (ppmv) & 50.02 & 50.04 & $\leq 0.06$ \\
Nitrous oxide, (ppmv) & {$[78]$} & {$[344]$} & {$[369]$} \\
Water vapor, (mg/m ${ }^{3}$ ) & 70.7 & 17.5 & 20.4 \\
Water vapor, (\% relative humidity) & 86 & 76 & 79 \\
\hline Ethanenitrile (acetonitrile), (ppmv) & $(0.25)$ & $(0.0052)$ & $(0.26)$ \\
Propanone (acetone), (ppmv) & $(0.094)$ & 0.018 & $(0.012)$ \\
1-Butanol, (ppmv) & $(0.0025)$ & $(0.00049)$ & 0.0032 \\
n-Dodecane, (ppmv) & 0.0073 & $(0.00053)$ & $(0.00026)$ \\
n-Tridecane, (ppmv) & 0.0092 & $(0.0011)$ & $(0.00047)$ \\
\hline Total nonmethane organic compounds & {$[3.6]$} & {$[0.35]$} & {$[0.65]$} \\
by EPA TO-12 method, (mg/m $\left.{ }^{3}\right)$ & & & \\
\hline \hline
\end{tabular}

1 Where PNL inorganic gas or vapor data was unavailable for tanks C-108 and C-109, OGIST results are given in brackets to indicate the data should be considered secondary results. Organic vapor results are from ORNL, with semiquantitative values in parentheses and quantitative values not in parentheses.

2 Data are from Huckaby $1995 a$.

3 Data are from Huckaby $1994 b$. 
WHC-SD-WM-ER-423 REV. 2

Table 4-1

Tank C-108 Quantitatively Measured Organic Compounds in SUMMA ${ }^{\text {TM }}$ Samples Analyses by Pacific Northwest Laboratory

\begin{tabular}{|c|c|c|c|c|c|}
\hline$\underset{\#}{\text { Cmpd }}$ & Compound & $\begin{array}{c}\text { CAS }^{1} \\
\text { Number }\end{array}$ & $\begin{array}{c}\text { Average }^{2} \\
\text { (ppmv) }\end{array}$ & $\begin{array}{c}\text { Standard } \\
\text { Deviation } \\
\text { (ppmv) }\end{array}$ & $\begin{array}{l}\mathrm{RSD}^{3} \\
(\%)\end{array}$ \\
\hline 1 & Methane ${ }^{4}$ & $74-82-8$ & {$[0.67]$} & {$[0.01]$} & [0.1] \\
\hline 2 & Trichlorofluoromethane & $75-69-4$ & 0.0095 & 0.00014 & 2 \\
\hline 3 & 1,1,2-Trichloro-1,2,2-triatuoroethane ${ }^{5}$ & $76-13-1$ & 0.0087 & 0.00060 & 7 \\
\hline 4 & Benzene & $71-43-2$ & $<0.002$ & - & - \\
\hline 5 & Toluene & $108-88-3$ & $<0.002$ & - & - \\
\hline
\end{tabular}

$1 \mathrm{CAS}=$ Chemical Abstract Service.

2 Average of 3 samples.

3 RSD = relative standard deviation. Burnum (1995) specifies the RSD should be less than $25 \%$.

4 Methane analyses were performed by OGIST and should be considered a secondary result (Ramussen 1994a).

5 Suspect contamination. 
WHC-SD-WM-ER-423 Rev. 2

Table 4-2

Tank C-108 Quantitatively Measured Organic Compounds in TST Samples -Analyses by Oak Ridge National Laboratory ${ }^{4}$

\begin{tabular}{clcccc}
\hline \hline $\begin{array}{c}\text { Cmpd } \\
\#\end{array}$ & Compound & $\begin{array}{c}\text { CAS }^{2} \\
\text { Number }\end{array}$ & $\begin{array}{c}\text { Average } \\
\text { (ppmv) }\end{array}$ & $\begin{array}{c}\text { Standard } \\
\text { Deviation } \\
\text { (ppmv) }\end{array}$ & $\begin{array}{c}\text { RSD }^{4} \\
\text { (\%) }\end{array}$ \\
\hline \hline 1 & Propanone (acetone) & $67-64-1$ & 0.018 & 0.019 & 110 \\
\hline \hline
\end{tabular}

1 Results in this table are quantitative (as defined in Section 4.1).

$2 \mathrm{CAS}=$ Chemical Abstract Service.

3 Average of 5 TST samples: 3 were $4-L$ and 2 were $1-L$.

4 RSD = relative standard deviation. Burnum (1995) specifies the RSD should be less than $25 \%$. 
WHC-SD-WM-ER-423 ReV. 2

Table 4-3

Tank C-108 Positively Identified Organic Compounds in TST Samples -Analyses by Oak Ridge National Laboratory ${ }^{1}$

\begin{tabular}{clrrrr}
\hline $\begin{array}{c}\text { Cmpd } \\
\#\end{array}$ & Compound & $\begin{array}{c}\text { CAS }^{2} \\
\text { Number }\end{array}$ & $\begin{array}{c}\text { Average } \\
\text { (ppmv) }\end{array}$ & $\begin{array}{c}\text { Standard } \\
\text { Deviation } \\
\text { (ppmv) }\end{array}$ & $\begin{array}{c}\text { RSD }^{4} \\
(\%)\end{array}$ \\
\hline 1 & Ethanenitrile (acetonitrile) & $75-05-8$ & 0.0052 & 0.0032 & 61 \\
2 & n-Hexane & $110-54-3$ & 0.00029 & 0.00064 & 224 \\
3 & Benzene & $71-43-2$ & 0.00038 & 0.00030 & 79 \\
4 & n-Heptane & $142-82-5$ & 0.00013 & 0.00030 & 224 \\
5 & Toluene & $108-88-3$ & 0.00024 & 0.00047 & 192 \\
6 & 2-Hexanone & $591-78-6$ & 0.00012 & 0.00024 & 193 \\
7 & n-Octane & $111-65-9$ & 0.00014 & 0.00028 & 201 \\
8 & 2-Heptanone & $110-43-0$ & 0.00016 & 0.00028 & 174 \\
9 & n-Nonane & $111-84-2$ & 0.00021 & 0.00028 & 136 \\
10 & n-Octanenitrile & $124-12-9$ & 0.000012 & 0.000026 & 224 \\
11 & n-Nonanenitrile & $2243-27-8$ & 0.000081 & 0.000077 & 95 \\
12 & n-Dodecane & $112-40-3$ & 0.00053 & 0.00058 & 110 \\
13 & n-Tridecane & $629-50-5$ & 0.0011 & 0.0011 & 97 \\
14 & Dibutyl butylphosphonate & $75-46-4$ & 0.000008 & 0.000004 & 55 \\
15 & Tributyl phosphate & $126-73-8$ & 0.000075 & 0.000069 & 92 \\
\hline \hline & & & & & \\
\hline
\end{tabular}

1 Results in this table are not quantitative (as defined in Section 4.1 ) because measured values in at least 1 of the samples are outside instrument calibration limits.

$2 \mathrm{CAS}=$ Chemical Abstract Service.

3 Average of 5 TST samples: 3 were 4-L and 2 were 1-L.

4 RSD = relative standard deviation. Burnum (1995) specifies the RSD should be less than $25 \%$. 
WHC-SD-WM-ER-423 Rev. 2

Table 4-4

Tank C-108 Positively Identified Compounds in TST Samples

for which Practical Holding Times were Exceeded Analyses by Oak Ridge National Laboratory ${ }^{1}$

\begin{tabular}{ccccccc}
\hline $\begin{array}{c}\text { Cmpd } \\
\#\end{array}$ & Compound & $\begin{array}{c}\text { CAS }^{2} \\
\text { Number }\end{array}$ & $\begin{array}{c}\text { Average } \\
\text { (ppmv) }\end{array}$ & $\begin{array}{c}\text { Standard } \\
\text { Deviation } \\
\text { (ppmv) }\end{array}$ & $\begin{array}{c}\mathrm{RSD}^{4} \\
(\%)\end{array}$ \\
\hline \hline 1 & $1-$ Butanol $^{5}$ & $71-36-3$ & 0.00049 & 0.00060 & 121 \\
\hline \hline
\end{tabular}

1 Practical holding times are defined and discussed in Section 4.1.

2 CAS $=$ Chemical Abstract Service.

3 Average of 5 TST samples: 3 were $4-L$ and 2 were $1-L$.

4 RSD $=$ relative standard deviation. Burnum (1995) specifies the RSD should be less than $25 \%$.

5 The concentration of this analyte was not quantitatively measured (as defined in Section 4.1), because the measured concentration was outside of the instrumental calibration limits. 
WHC-SD-WM-ER-423 Rev. 2

Table 4-5

Tank C-108 Comparison of Organic Compounds in TST and SUMMA Th Samples Analyses by Pacific Northwest Laboratory and Oak Ridge National Laboratory

\begin{tabular}{|c|c|c|c|c|}
\hline Compound & $\begin{array}{c}\text { CAS }^{1} \\
\text { Number }\end{array}$ & $\begin{array}{c}\text { TST } \\
\text { Average }^{2} \\
\text { (ppmv) }\end{array}$ & $\begin{array}{l}\text { SUMMA }^{\mathrm{T}} \\
\text { Average }^{3} \\
\text { (ppmv) }\end{array}$ & $\begin{array}{c}\text { PRD }^{4} \\
(\%)\end{array}$ \\
\hline Benzene & $71-43-2$ & 0.00038 & $<0.002$ & - \\
\hline Toluene & $108-88-3$ & 0.00024 & $<0.002$ & - \\
\hline
\end{tabular}

$1 \mathrm{CAS}=$ Chemical Abstract Service.

2 Average of 5 TST samples: 3 were $4-L$ and 2 were $1-L$.

3 Average of 3 samples.

$4 \mathrm{PRD}=$ percent relative difference. Keller (1994) requires the PRD to be less than $20 \%$. 
WHC-SD-WM-ER-423 Rev. 2

Table 4-6

Tank C-108 Tentatively Identified Organic Compounds in SUMMA ${ }^{\text {TM }}$ Samples -

\begin{tabular}{clccc}
\hline $\begin{array}{c}\text { Cmpd } \\
\#\end{array}$ & Compound & $\begin{array}{c}\mathrm{CAS}^{1} \\
\text { Number }\end{array}$ & $\begin{array}{c}\text { Average }^{2} \\
\mathrm{mg}^{3} \mathrm{~m}^{3}\end{array}$ & $\begin{array}{c}\text { Standard } \\
\text { Deviation } \\
\mathrm{mg} / \mathrm{m}^{3}\end{array}$ \\
\hline \hline 1 & Ethanenitrile (acetaldehyde) & $75-07-0$ & 0.10 & 0.02 \\
2 & Propanone (acetone) & $67-64-1$ & 0.09 & 0.03 \\
\hline \hline Sum of tentatively identified compounds: & & 0.19 \\
\hline \hline
\end{tabular}

$1 \mathrm{CAS}=$ Chemical Abstract Service.

2 Average of 3 samples; presented values are estimates. 
Table $4-7$

Tank C-108 Tentatively Identified Organic Compounds in TST Samples in Order of Chromatographic Elution Analyses by Oak Ridge National Laboratory

\begin{tabular}{|c|c|c|c|c|}
\hline Cmpd & Compound & $\begin{array}{l}\text { CAS }^{1} \\
\text { Number }\end{array}$ & $\begin{array}{c}\text { Average }^{2} \\
\left(\mathrm{mg} / \mathrm{m}^{3}\right)\end{array}$ & $\begin{array}{c}\text { Standard } \\
\text { Deviation } \\
\left(\mathrm{mg} / \mathrm{m}^{3}\right)\end{array}$ \\
\hline 1 & 1-Butene & $106-98-9$ & 0.038 & 0.053 \\
\hline 2 & Methane, trichlorofluoro & $75-69-4$ & 0.042 & 0.032 \\
\hline 3 & Acetic Acid & $64-19-7$ & 0.083 & 0.117 \\
\hline 4 & Acetic Acid & $64-19-7$ & 0.038 & 0.085 \\
\hline 5 & Propanoic acid & $79-09-4$ & 0.003 & 0.008 \\
\hline 6 & Hexanal & $66-25-1$ & 0.010 & 0.023 \\
\hline 7 & Cyclotrisiloxane, hexamethyl & $541-05-9$ & 0.026 & 0.020 \\
\hline 8 & Alkanone & & 0.012 & 0.026 \\
\hline 9 & Heptanal & $111-71-7$ & 0.009 & 0.021 \\
\hline 10 & 4H-1,2,4-Triazol-3-amine, 4-ethyl & $42786-06-1$ & 0.004 & 0.006 \\
\hline 11 & Ethanol, 2-Butoxy & $111-76-2$ & 0.001 & 0.001 \\
\hline 12 & Cyclobutane, 1,1,2,3,3-pentamethyl & $57905-86-9$ & 0.002 & 0.004 \\
\hline 13 & Cyclotetrasiloxane, octamethyl & $556-67-2$ & 0.020 & 0.026 \\
\hline 14 & Benzene, (1-methylethenyl)- & $98-83-9$ & 0.001 & 0.002 \\
\hline 15 & Octanal & $124-13-0$ & 0.016 & 0.029 \\
\hline 16 & 1-Hexanol, 2-Ethyl & $104-76-7$ & 0.006 & 0.005 \\
\hline 17 & 1-Octanol & $111-87-5$ & 0.004 & 0.009 \\
\hline 18 & Ethanone, 1-phenyl & $98-86-2$ & 0.001 & 0.001 \\
\hline 19 & Benzenemethanol, a,a-dimethyl & $617-94-7$ & 0.006 & 0.002 \\
\hline 20 & Nonanal & $124-19-6$ & 0.018 & 0.024 \\
\hline 21 & Benzoic acid, 2-[trimethylsilyl)oxy]-trimeth & $3789-85-3$ & 0.002 & 0.002 \\
\hline 22 & 1-Nonanol & $143-08-8$ & 0.002 & 0.003 \\
\hline 23 & Decanal & $112-31-2$ & 0.011 & 0.013 \\
\hline 24 & Benzenamine, N-phenyl & $122-39-4$ & 0.001 & 0.002 \\
\hline 25 & 1,3,5,7-Tetraazatricyclo[3.3.1.13,7]decane & $100-97-0$ & 0.001 & 0.002 \\
\hline
\end{tabular}




\begin{tabular}{|c|c|c|c|c|}
\hline$\underset{\#}{\text { Cmpd }}$ & Compound & $\begin{array}{c}\text { CAS }^{\dagger} \\
\text { Number }\end{array}$ & $\begin{array}{c}\text { Average }^{2} \\
\left(\mathrm{mg} / \mathrm{m}^{3}\right)\end{array}$ & $\begin{array}{c}\text { Standard } \\
\text { Deviation } \\
\left(\mathrm{mg} / \mathrm{m}^{3}\right)\end{array}$ \\
\hline 26 & 2,5-Pyrrolidinedione, 1-methyl & $1121-07-9$ & 0.001 & 0.001 \\
\hline 27 & Undecanal & $112-44-7$ & $<0.001$ & - \\
\hline 28 & Decanoic acid & $334-48-5$ & $<0.001$ & - \\
\hline 29 & Alkane & & $<0.001$ & - \\
\hline 30 & Butanoic acid, butyl. ester and siloxane & $109-21-7$ & $<0.001$ & - \\
\hline 31 & Alkane & & 0.002 & 0.002 \\
\hline 32 & Butanoic acid, butyl ester & $109-21-7$ & $<0.001$ & - \\
\hline 33 & n-Tetradecane & $629-59-4$ & 0.002 & 0.003 \\
\hline 34 & Dodecanal & $112-54-9$ & $<0.001$ & - \\
\hline 35 & Mixture & & $<0.001$ & - \\
\hline 36 & Decane, 1,1'-oxybis & $2456-28-2$ & $<0.001$ & - \\
\hline 37 & 5,9-Undecadio-2-one, 6,10-dimethyl-,(Z) & $3879-26-3$ & 0.002 & 0.002 \\
\hline 38 & 2,5-Cyclohexadiene, 1,4-dione, 2,6-bis(1 & $719-22-2$ & $<0.001$ & - \\
\hline 39 & Alkanol and alkyl benzene & & 0.001 & 0.002 \\
\hline 40 & C12-Alkene & & 0.003 & 0.002 \\
\hline 41 & Alkene & & $<0.001$ & - \\
\hline 42 & 2,5-Cyclohexadiene-1,4-dione, 2,6-bis & $719-22-2$ & 0.002 & 0.002 \\
\hline 43 & n-Hexadecane & $544-76-3$ & 0.001 & 0.001 \\
\hline 44 & Tetradecanoic acid & $544-63-8$ & 0.002 & 0.004 \\
\hline 45 & Decanoic acid & $334-48-5$ & $<0.001$ & - \\
\hline 46 & Dodécanoic acid & $143-07-7$ & 0.010 & 0.007 \\
\hline 47 & n-Tetradecane & $629-59-4$ & $<0.001$ & - \\
\hline 48 & Dodecane, 2-methyl-6-propyl & $55045-08-4$ & 0.003 & 0.004 \\
\hline 49 & Propanoic acid, 2-methyl-1(1,1-dimethyle & $74381-40-1$ & 0.017 & 0.009 \\
\hline 50 & Benzenamine, $\mathrm{N}$-phenyl & $122-39-4$ & 0.009 & 0.006 \\
\hline 51 & Hexadecanamide & $629-54-9$ & 0.001 & 0.001 \\
\hline 52 & N-Hexyl-benzene-sulfonamide & & 0.003 & 0.003 \\
\hline 53 & para-T-Butyl Benzoic acid, methyl ester & & 0.002 & 0.003 \\
\hline
\end{tabular}


WHC-SD-WM-ER-423 REv. 2

\begin{tabular}{|c|c|c|c|c|}
\hline$\underset{\#}{\text { Cmpd }}$ & Compound & $\begin{array}{c}\text { CAS }^{1} \\
\text { Number }\end{array}$ & $\begin{array}{l}\text { Average }^{2} \\
\left(\mathrm{mg} / \mathrm{m}^{3}\right)\end{array}$ & $\begin{array}{c}\text { Standard } \\
\text { Deviation } \\
\left(\mathrm{mg} / \mathrm{m}^{3}\right)\end{array}$ \\
\hline 54 & 1,2-Benzenedicarboxylic acid, bis-(2ethyl & $117-81-7$ & 0.001 & 0.002 \\
\hline 55 & Octadecanoic acid & $57-11-4$ & 0.001 & 0.002 \\
\hline 56 & Mixture & & 0.001 & 0.002 \\
\hline 57 & 1-Hexadecanol and others & & 0.002 & 0.003 \\
\hline 58 & Mixture (alkane and alkanoic acid) & & 0.002 & 0.002 \\
\hline 59 & Mixture & & 0.002 & 0.002 \\
\hline 60 & 9-Octadecenoic acid, (Z)- & $112-80-1$ & 0.003 & 0.004 \\
\hline 61 & 1,1'-Biphenyl, 2,2'-diethyl & $13049-35-9$ & 0.001 & 0.001 \\
\hline 62 & Tetradecanoic acid & $544-63-8$ & 0.055 & 0.037 \\
\hline 63 & Benzenesulfonamide, N-butyl & $3622-84-2$ & 0.132 & 0.103 \\
\hline 64 & Tetradecanoic acid, 12-methyl, (S) & $5746-58-7$ & 0.005 & 0.004 \\
\hline 65 & Cyclohexanol, 1,1'-dioxybis-and others & & $<0.001$ & - \\
\hline 66 & Pentadecanoic acid & $1002-84-2$ & 0.023 & 0.016 \\
\hline 67 & C14-Alkene & & 0.016 & 0.028 \\
\hline 68 & 1-Hexadecanol & $36653-82-4$ & 0.012 & 0.020 \\
\hline 69 & Alkanol & & 0.001 & 0.003 \\
\hline 70 & n-Hexadecane & $544-76-3$ & 0.001 & 0.002 \\
\hline 71 & Alkane & & 0.004 & 0.010 \\
\hline 72 & 9-Hexadecenoic acid & $2091-29-4$ & 0.062 & 0.052 \\
\hline 73 & Hexadecanoic acid & $57-10-3$ & 0.120 & 0.088 \\
\hline 74 & 1,2-Benzenedicarboxylic acid, butyl 2-me & $17851-53-5$ & 0.004 & 0.006 \\
\hline 75 & Alkanol & & $<0.001$ & - \\
\hline 76 & 1-Hexadecanol & $36653-82-4$ & 0.001 & 0.003 \\
\hline 77 & 1-Hexadecanol, acetate & $629-70-9$ & 0.002 & 0.004 \\
\hline 78 & 1-Hexadecanol, 2-methyl & $2490-48-4$ & 0.002 & 0.002 \\
\hline 79 & Hexadecanoic acid & $57-10-3$ & 0.002 & 0.004 \\
\hline 80 & Hexadeanoic acid, 1-methylethyl ester & $142-91-6$ & 0.007 & 0.006 \\
\hline \multicolumn{2}{|c|}{ Sum of tentatively identified compounds: } & & 0.881 & \\
\hline
\end{tabular}




\section{WHC-SD-WM-ER-423 Rev. 2}

$1 \mathrm{CAS}=$ Chemical Abstract Service.

2 Average of 5 TST samples; 3 were 4-L and 2 were 1-L; presented values are estimates. 
WHC-SD-WM-ER-423 REV. 2

Table 4-8

Tank C-108 Tentatively Identified Organic Compounds in TST Samples Sorted Alphanumerically --

Analyses by Oak Ridge National Laboratory

\begin{tabular}{|c|c|c|c|c|}
\hline$\underset{\#}{\text { Cmpd }}$ & Compound & $\begin{array}{l}\text { CAS }^{1} \\
\text { Number }\end{array}$ & $\begin{array}{c}\text { Average }^{2} \\
\left(\mathrm{mg} / \mathrm{m}^{3}\right)\end{array}$ & $\begin{array}{l}\text { Standard } \\
\text { Deviation } \\
\left(\mathrm{mg} / \mathrm{m}^{3}\right)\end{array}$ \\
\hline 1 & 1-Butene & $106-98-9$ & 0.038 & 0.053 \\
\hline 78 & 1-Hexadecanol, 2-methyl & $2490-48-4$ & 0.002 & 0.002 \\
\hline 76 & 1-Hexadecanol & $36653-82-4$ & 0.001 & 0.003 \\
\hline 57 & 1-Hexadecanol and others & & 0.002 & 0.003 \\
\hline 22 & 1-Nonanol & $143-08-8$ & 0.002 & 0.003 \\
\hline 68 & 1-Hexadecanol & $36653-82-4$ & 0.012 & 0.020 \\
\hline 17 & 1-Octanol & $111-87-5$ & 0.004 & 0.009 \\
\hline 16 & 1-Hexanol, 2-Ethyl & $104-76-7$ & 0.006 & 0.005 \\
\hline 77 & 1-Hexadecanol, acetate & $629-70-9$ & 0.002 & 0.004 \\
\hline 61 & 1,1'-Biphenyl, 2,2'-diethyl & $13049-35-9$ & 0.001 & 0.001 \\
\hline 54 & 1,2-Benzenedicarboxylic acid, bis-(2ethyl & $117-81-7$ & 0.001 & 0.002 \\
\hline 74 & 1,2-Benzenedicarboxylic acid, butyl 2-me & $17851-53-5$ & 0.004 & 0.006 \\
\hline 25 & 1,3,5,7-Tetraazatricyclo[3,3.1.13,7]decane & $100-97-0$ & 0.001 & 0.002 \\
\hline 26 & 2,5-Pyrrolidinedione, 1-methyl & $1121-07-9$ & 0.001 & 0.001 \\
\hline 38 & 2,5-Cyclohexadiene, 1,4-dione, 2,6-bis(1 & $719-22-2$ & $<0.001$ & - \\
\hline 42 & 2,5-Cyclohexadiene-1,4-dione, 2,6-bis & $719-22-2$ & 0.002 & 0.002 \\
\hline 10 & 4H-1,2,4-Triazol-3-amine, 4-ethyl & $42786-06-1$ & 0.004 & 0.006 \\
\hline 37 & 5,9-Undecadio-2-one, 6,10-dimethyl-, (Z) & $3879-26-3$ & 0.002 & 0.002 \\
\hline 60 & 9-Octadecenoic acid, (Z)- & $112-80-1$ & 0.003 & 0.004 \\
\hline 72 & 9-Hexadecenoic acid & $2091-29-4$ & 0.062 & 0.052 \\
\hline 3 & Acetic Acid & $64-19-7$ & 0.083 & 0.117 \\
\hline 4 & Acetic Acid & $64-19-7$ & 0.038 & 0.085 \\
\hline 29 & Alkane & & $<0.001$ & - \\
\hline 31 & Alkane & & 0.002 & 0.002 \\
\hline 71 & Alkane & & 0.004 & 0.010 \\
\hline 39 & Alkanol and alkyl benzene & & 0.001 & 0.002 \\
\hline
\end{tabular}


WHC-SD-WM-ER-423 Rev. 2

\begin{tabular}{|c|c|c|c|c|}
\hline$\underset{\#}{\text { Cmpd }}$ & Compound & $\begin{array}{c}\text { CAS }^{\uparrow} \\
\text { Number }\end{array}$ & $\begin{array}{c}\text { Average }^{2} \\
\left(\mathrm{mg} / \mathrm{m}^{3}\right)\end{array}$ & $\begin{array}{c}\text { Standard } \\
\text { Deviation } \\
\left(\mathrm{mg} / \mathrm{m}^{3}\right)\end{array}$ \\
\hline 69 & Alkanol & & 0.001 & 0.003 \\
\hline 75 & Alkanol & & $<0.001$ & - \\
\hline 8 & Alkanone & & 0.012 & 0.026 \\
\hline 41 & Alkene & & $<0.001$ & - \\
\hline 24 & Benzenamine, $\mathrm{N}$-phenyl & $122-39-4$ & 0.001 & 0.002 \\
\hline 50 & Benzenamine, $\mathrm{N}$-phenyl & $122-39-4$ & 0.009 & 0.006 \\
\hline 14 & Benzene, (1-methylethenyl)- & $98-83-9$ & 0.001 & 0.002 \\
\hline 19 & Benzenemethanol, a,a-dimethyl & $617-94-7$ & 0.006 & 0.002 \\
\hline 63 & Benzenesulfonamide, N-butyl & $3622-84-2$ & 0.132 & 0.103 \\
\hline 21 & Benzoic acid, 2-[trimethylsilyl)oxy]-trimeth & $3789-85-3$ & 0.002 & 0.002 \\
\hline 30 & Butanoic acid, butyl ester and siloxane & $109-21-7$ & $<0.001$ & - \\
\hline 32 & Butanoic acid, butyl ester & $109-21-7$ & $<0.001$ & - \\
\hline 40 & C12-Alkene & & 0.003 & 0.002 \\
\hline 67 & C14-Alkene & & 0.016 & 0.028 \\
\hline 12 & Cyclobutane, 1,1,2,3,3-pentamethyl & $.57905-86-9$ & 0.002 & 0.004 \\
\hline 65 & Cyclohexanol, 1,1'-dioxybis-and others & & $<0.001$ & - \\
\hline 13 & Cyclotetrasiloxane, octamethy! & $556-67-2$ & 0.020 & 0.026 \\
\hline 7 & Cyclotrisiloxane, hexamethyl & $541-05-9$ & 0.026 & 0.020 \\
\hline 23 & Decanal & $112-31-2$ & 0.011 & 0.013 \\
\hline 36 & Decane, $1,1^{\prime}$-oxybis & $2456-28-2$ & $<0.001$ & - \\
\hline 28 & Decanoic acid & $334-48-5$ & $<0.001$ & - \\
\hline 45 & Decanoic acid & $334-48-5$ & $<0.001$ & - \\
\hline 34 & Dodecanal & $112-54-9$ & $<0.001$ & - \\
\hline 48 & Dodecane, 2-methyl-6-propyl & $55045-08-4$ & 0.003 & 0.004 \\
\hline 46 & Dodecanoic acid & $143-07-7$ & 0.010 & 0.007 \\
\hline 11 & Ethanol, 2-Butoxy & $111-76-2$ & 0.001 & 0.001 \\
\hline 18 & Ethanone, 1-phenyl & $98-86-2$ & 0.001 & 0.001 \\
\hline 9 & Heptanal & $111-71-7$ & 0.009 & 0.021 \\
\hline
\end{tabular}




\begin{tabular}{|c|c|c|c|c|}
\hline$\underset{\#}{C m p d}$ & Compound & $\begin{array}{l}\text { CAS }^{1} \\
\text { Number }\end{array}$ & $\begin{array}{c}\text { Average }^{2} \\
\left(\mathrm{mg} / \mathrm{m}^{3}\right)\end{array}$ & $\begin{array}{c}\text { Standard } \\
\text { Deviation } \\
\left(\mathrm{mg} / \mathrm{m}^{3}\right)\end{array}$ \\
\hline 80 & Hexadeanoic acid, 1-methylethyl ester & $142-91-6$ & 0.007 & 0.006 \\
\hline 51 & Hexadecanamide & $629-54-9$ & 0.001 & 0.001 \\
\hline 73 & Hexadecanoic acid & $57-10-3$ & 0.120 & 0.088 \\
\hline 79 & Hexadecanoic acid & $57-10-3$ & 0.002 & 0.004 \\
\hline 6 & Hexanal & $66-25-1$ & 0.010 & 0.023 \\
\hline 2 & Methane, trichlorofluoro & $75-69-4$ & 0.042 & 0.032 \\
\hline 35 & Mixture & & $<0.001$ & - \\
\hline 56 & Mixture & & 0.001 & 0.002 \\
\hline 58 & Mixture (alkane and alkanoic acid) & & 0.002 & 0.002 \\
\hline 59 & Mixture & & 0.002 & 0.002 \\
\hline 52 & N-Hexyl-benzene-sulfonamide & & 0.003 & 0.003 \\
\hline 43 & n-Hexadecane & $544-76-3$ & 0.001 & 0.001 \\
\hline 70 & n-Hexadecane & $544-76-3$ & 0.001 & 0.002 \\
\hline 33 & n-Tetradecane & $629-59-4$ & 0.002 & 0.003 \\
\hline 47 & n-Tetradecane & $629-59-4$ & $<0.001$ & - \\
\hline 20 & Nonanal & $124-19-6$ & 0.018 & 0.024 \\
\hline 55 & Octadecanoic acid & $57-11-4$ & 0.001 & 0.002 \\
\hline 15 & Octanal & $124-13-0$ & 0.016 & 0.029 \\
\hline 53 & para-T-Butyl Benzoic acid, methyl ester & & 0.002 & 0.003 \\
\hline 66 & Pentadecanoic acid & $1002-84-2$ & 0.023 & 0.016 \\
\hline 5 & Propanoic acid & $79-09-4$ & 0.003 & 0.008 \\
\hline 49 & Propanoic acid, 2-methyl-1(1,1-dimethyle & $74381-40-1$ & 0.017 & 0.009 \\
\hline 44 & Tetradecanoic acid & $544-63-8$ & 0.002 & 0.004 \\
\hline 62 & Tetradecanoic acid & $544-63-8$ & 0.055 & 0.037 \\
\hline 64 & Tetradecanoic acid, 12-methyl, (S) & $5746-58-7$ & 0.005 & 0.004 \\
\hline 27 & Undecanel & $112-44-7$ & $<0.001$ & $=$ \\
\hline
\end{tabular}

1. CAS = Chemical Abstract Service.

2 Average of 5 TST samples; 3 were $4-L$ and 2 were 1-L; presented values are estimates. 
Table 4-9

Tank C-108 Tentatively Identified Organic Compounds in TST Samples Sorted by Estimated Concentration-

Analyses by Oak Ridge National Laboratory

\begin{tabular}{|c|c|c|c|c|}
\hline$\underset{\#}{\text { Cmpd }}$ & Compound & $\begin{array}{l}\text { CAS }^{1} \\
\text { Number }\end{array}$ & $\begin{array}{l}\text { Average }^{2} \\
\left(\mathrm{mg} / \mathrm{m}^{3}\right)\end{array}$ & $\begin{array}{c}\text { Standard } \\
\text { Deviation } \\
\left(\mathrm{mg} / \mathrm{m}^{3}\right) \\
\end{array}$ \\
\hline 63 & Benzenesulfonamide, N-butyl & $3622-84-2$ & 0.132 & 0.103 \\
\hline 73 & Hexadecanoic acid & $57-10-3$ & 0.120 & 0.088 \\
\hline 3 & Acetic Acid & $64-19-7$ & 0.083 & 0.117 \\
\hline 72 & 9-Hexadecenoic acid & $2091-29-4$ & 0.062 & 0.052 \\
\hline 62 & Tetradecanoic acid & $544-63-8$ & 0.055 & 0.037 \\
\hline 2 & Methane, trichlorofluoro & $75-69-4$ & 0.042 & 0.032 \\
\hline 4 & Acetic Acid & $64-19-7$ & 0.038 & 0.085 \\
\hline 1 & 1-Butene & $106-98-9$ & 0.038 & 0.053 \\
\hline 7 & Cyclotrisiloxane, hexamethyl & $541-05-9$ & 0.026 & 0.020 \\
\hline 66 & Pentadecanoic acid & $1002-84-2$ & 0.023 & 0.016 \\
\hline 13 & Cyclotetrasiloxane, octamethyl & $556-67-2$ & 0.020 & 0.026 \\
\hline 20 & Nonanal & $124-19-6$ & 0.018 & 0.024 \\
\hline 49 & Propanoic acid, 2-methyl-1(1,1-dimethyle & $74381-40-1$ & 0.017 & 0.009 \\
\hline 67 & C14-Alkene & & 0.016 & 0.028 \\
\hline 15 & Octanal & $124-13-0$ & 0.016 & 0.029 \\
\hline 68 & 1-Hexadecanol & $36653-82-4$ & 0.012 & 0.020 \\
\hline 8 & Alkanone & & 0.012 & 0.026 \\
\hline 23 & Decanal & $112-31-2$ & 0.011 & 0.013 \\
\hline 46 & Dodecanoic acid & $143-07-7$ & 0.010 & 0.007 \\
\hline 6 & Hexanal & $66-25-1$ & 0.010 & 0.023 \\
\hline 9 & Heptanal & $111-71-7$ & 0.009 & 0.021 \\
\hline 50 & Benzenamine, N-phenyl & $122-39-4$ & 0.009 & 0.006 \\
\hline 80 & Hexadeanoic acid, 1-methylethyl ester & $142-91-6$ & 0.007 & 0.006 \\
\hline 19 & Benzenemethanol, a,a-dimethyl & $617-94-7$ & 0.006 & 0.002 \\
\hline 16 & 1-Hexanol, 2-Ethyl & $104-76-7$ & 0.006 & 0.005 \\
\hline 64 & Tetradecanoic acid, 12-methyl, (S) & $5746-58-7$ & 0.005 & 0.004 \\
\hline
\end{tabular}




\begin{tabular}{|c|c|c|c|c|}
\hline$\underset{\#}{\text { Cmpd }}$ & Compound & $\begin{array}{l}\text { CAS' } \\
\text { Number }\end{array}$ & $\begin{array}{c}\text { Average }{ }^{2} \\
\left(\mathrm{mg} / \mathrm{m}^{3}\right)\end{array}$ & $\begin{array}{c}\text { Standard } \\
\text { Deviation } \\
\left(\mathrm{mg} / \mathrm{m}^{3}\right) \\
\end{array}$ \\
\hline 10 & 4H-1,2,4-Triazol-3-amine, 4-ethyl & $42786-06-1$ & 0.004 & 0.006 \\
\hline 71 & Alkane & & 0.004 & 0.010 \\
\hline 74 & 1,2-Benzenedicarboxylic acid, butyl 2-me & $17851-53-5$ & 0.004 & 0.006 \\
\hline 17 . & 1-Octanol & $111-87-5$ & 0.004 & 0.009 \\
\hline 5 & Propanoic acid & $79-09-4$ & 0.003 & 0.008 \\
\hline 40 & C12-Alkene & & 0.003 & 0.002 \\
\hline 48 & Dodecane, 2-methyl-6-propyl & $55045-08-4$ & 0.003 & 0.004 \\
\hline 60 & 9-Octadecenoic acid, (Z)- & $112-80-1$ & 0.003 & 0.004 \\
\hline 52 & N-Hexyl-benzene-sulfonamide & & 0.003 & 0.003 \\
\hline 31 & Alkane & & 0.002 & 0.002 \\
\hline 37 & 5,9-Undecadio-2-one, 6,10-dimethyl-, (Z) & $3879-26-3$ & 0.002 & 0.002 \\
\hline 33 & n-Tetradecane & $629-59-4$ & 0.002 & 0.003 \\
\hline 21 & Benzoic acid, 2-[trimethyisily)joxy]-trimeth & $3789-85-3$ & 0.002 & 0.002 \\
\hline 22 & 1-Nonanol & $143-08-8$ & 0.002 & 0.003 \\
\hline 79 & Hexadecanoic acid & $57-10-3$ & 0.002 & 0.004 \\
\hline 42 & 2,5-Cyclohexadiene-1,4-dione, 2,6-bis & $719-22-2$ & 0.002 & 0.002 \\
\hline 78 & 1-Hexadecanol, 2-methyl & $2490-48-4$ & 0.002 & 0.002 \\
\hline 44 & Tetradecanoic acid & $544-63-8$ & 0.002 & 0.004 \\
\hline 77 & 1-Hexadecanol, acetate & $629-70-9$ & 0.002 & 0.004 \\
\hline 12 & Cyclobutane, 1,1,2,3,3-pentamethyl & $57905-86-9$ & 0.002 & 0.004 \\
\hline 59 & Mixture & & 0.002 & 0.002 \\
\hline 58 & Mixture (alkane and alkanoic acid) & & 0.002 & 0.002 \\
\hline 57 & 1-Hexadecanol and others & & 0.002 & 0.003 \\
\hline 53 & para-T-Butyl Benzoic acid, methyl ester & & 0.002 & 0.003 \\
\hline 51 & Hexadecanamide & $629-54-9$ & 0.001 & 0.001 \\
\hline 35 & Mixture & & $<0.001$ & - \\
\hline 36 & Decane, 1,1'-oxybis & $2456-28-2$ & $<0.001$ & - \\
\hline 54 & 1,2-Benzenedicarboxylic acid, bis-(2ethyl & $117-81-7$ & 0.001 & 0.002 \\
\hline
\end{tabular}




\begin{tabular}{|c|c|c|c|c|}
\hline Cmpd & Compound & $\begin{array}{l}\text { CAS }^{1} \\
\text { Number }\end{array}$ & $\begin{array}{l}\text { Average }^{2} \\
\left(\mathrm{mg} / \mathrm{m}^{3}\right)\end{array}$ & $\begin{array}{c}\text { Standard } \\
\text { Deviation } \\
\left(\mathrm{mg} / \mathrm{m}^{3}\right)\end{array}$ \\
\hline 55 & Octadecanoic acid & $57-11-4$ & 0.001 & 0.002 \\
\hline 56 & Mixture & & 0.001 & 0.002 \\
\hline 18 & Ethanone, 1-phenyl & $98-86-2$ & 0.001 & 0.001 \\
\hline 38 & 2,5-Cyclohexadiene, 1,4-dione, 2,6-bis(1 & $719-22-2$ & $<0.001$ & - \\
\hline 47 & n-Tetradecane & $629-59-4$ & $<0.001$ & - \\
\hline 34 & Dodecanal & $112-54-9$ & $<0.001$ & - \\
\hline 61 & 1,1'-Bjphenyl, 2,2'-diethyl & $13049-35-9$ & 0.001 & 0.001 \\
\hline 32 & Butanoic acid, butyl ester & $109-21-7$ & $<0.001$ & - \\
\hline 30 & Butanoic acid, butyl ester and siloxane & $109-21-7$ & $<0.001$ & - \\
\hline 29 & Alkane & & $<0.001$ & $-\cdots$ \\
\hline 65 & Cyclohexanol, 1,1'-dioxybis-and others & & $<0.001$ & - \\
\hline 14 & Benzene, (1-methylethenyl)- & $98-83-9$ & 0.001 & 0.002 \\
\hline 39 & Alkanol and alkyl benzene & & 0.001 & 0.002 \\
\hline 11 & Ethanol, 2-Butoxy & $111-76-2$ & 0.001 & 0.001 \\
\hline 69 & Alkanol & & 0.001 & 0.003 \\
\hline 70 & n-Hexadecane & $544-76-3$ & 0.001 & 0.002 \\
\hline 28 & Decanoic acid & $334-48-5$ & $<0.001$ & - \\
\hline 27 & Undecanal & $112-44-7$ & $<0.001$ & - \\
\hline 26 & 2,5-Pyrrolidinedione, 1-methyl & $1121-07-9$ & 0.001 & 0.001 \\
\hline 25 & 1,3,5,7-Tetraazatricyclo[3.3.1.13,7]decane & $100-97-0$ & 0.001 & 0.002 \\
\hline 75 & Alkanol & & $<0.001$ & - \\
\hline 76 & 1-Hexadecanol & $36653-82-4$ & 0.001 & 0.003 \\
\hline 45 & Decanoic acid & $334-48-5$ & $<0.001$ & - \\
\hline 43 & $\mathrm{n}$-Hexadecane & $544-76-3$ & 0.001 & 0.001 \\
\hline 41 & Alkene & & $<0.001$ & - \\
\hline 24 & Benzenamine, $N$-phenyl & $122-39-4$ & 0.001 & 0.002 \\
\hline
\end{tabular}

1 CAS $=$ Chemical Abstract Service

2 Average of 5 TST samples; 3 were 4-L and 2 were 1-L; presented values are estimates. 
WHC-SD-WM-ER-423 Rev. 2 